Article

\title{
Biochemical Characterization of New Gemifloxacin Schiff Base (GMFX-o-phdn) Metal Complexes and Evaluation of Their Antimicrobial Activity against Some Phyto- or Human Pathogens
}

\author{
Hazem S. Elshafie ${ }^{1}\left(\mathbb{D}\right.$, Sadeek A. Sadeek ${ }^{2}$, Ippolito Camele ${ }^{1, *(\mathbb{D})}$ and Amira A. Mohamed ${ }^{3}$ (D) \\ 1 School of Agricultural, Forestry, Food and Environmental Sciences, University of Basilicata, 85100 Potenza, \\ Italy; hs.elshafie@gmail.com \\ 2 Department of Chemistry, Faculty of Science, Zagazig University, Zagazig 44519, Egypt; s_sadeek@zu.edu.eg \\ 3 Department of Basic Science, Zagazig Higher Institute of Engineering and Technology, Zagazig 44519, Egypt; \\ amira222283@yahoo.com \\ * Correspondence: ippolito.camele@unibas.it; Tel.: +39-0971-205544; Fax: +39-0971-205503
}

Citation: Elshafie, H.S.; Sadeek, S.A.; Camele, I.; Mohamed, A.A.

Biochemical Characterization of New Gemifloxacin Schiff Base (GMFX-o-phdn) Metal Complexes and Evaluation of Their

Antimicrobial Activity against Some Phyto- or Human Pathogens. Int. J. Mol. Sci. 2022, 23, 2110. https:// doi.org/10.3390/ijms23042110

Academic Editor: Dharmendra Kumar Yadav

Received: 16 December 2021 Accepted: 11 February 2022 Published: 14 February 2022

Publisher's Note: MDPI stays neutral with regard to jurisdictional claims in published maps and institutional affiliations.

Copyright: (C) 2022 by the authors. Licensee MDPI, Basel, Switzerland. This article is an open access article distributed under the terms and conditions of the Creative Commons Attribution (CC BY) license (https:// creativecommons.org/licenses/by/ $4.0 /)$.

\begin{abstract}
Four novel ligand-metal complexes were synthesized through the reaction of Fe(III), pleaseCo(II), Zn(II), and $\mathrm{Zr}(\mathrm{IV})$ with Schiff base gemifloxacin reacted with ortho-phenylenediamine (GMFX-o-phdn) to investigate their biological activities. Elemental analysis, FT-IR, ${ }^{1} \mathrm{H}$ NMR, UVvisible, molar conductance, melting points, magnetic susceptibility, and thermal analyses have been carried out for insuring the chelation process. The antimicrobial activity was carried out against Monilinia fructicola, Aspergillus flavus, Penicillium italicum, Botrytis cinerea, Escherichia coli, Bacillus cereus, Pseudomonas fluorescens, and P. aeruginosa. The radical scavenging activity (RSA\%) was in vitro evaluated using ABTS method. FT-IR spectra indicated that GMFX-o-phdn chelated with metal ions as a tetradentate through oxygen of carboxylate group and nitrogen of azomethine group. The data of infrared, ${ }^{1} \mathrm{H}$ NMR, and molar conductivity indicate that GMFX-o-phdn reacted as neutral tetra dentate ligand $\left(\mathrm{N}_{2} \mathrm{O}_{2}\right)$ with metal ions through the two oxygen atoms of the carboxylic group (oxygen containing negative charge) and two nitrogen atoms of azomethine group (each nitrogen containing a lone pair of electrons) (the absent of peak corresponding to $v(\mathrm{COOH})$ at $1715 \mathrm{~cm}^{-1}$, the shift of azomethine group peak from $1633 \mathrm{~cm}^{-1}$ to around $1570 \mathrm{~cm}^{-1}$, the signal at $11 \mathrm{ppm}$ of $\mathrm{COOH}$ and the presence of the chloride ions outside the complex sphere). Thermal analyses (TG-DTG/DTA) exhibited that the decaying of the metal complexes exists in three steps with the final residue metal oxide. The obtained data from DTA curves reflect that the degradation processes were exothermic or endothermic. Results showed that some of the studied complexes exhibited promising antifungal activity against most of the tested fungal pathogens, whereas they showed higher antibacterial activity against $E$. coli and B. cereus and low activity against $P$. fluorescens and $P$. aeruginosa. In addition, GMFX-o-phdn and its metal complexes showed strong antioxidant effect. In particular, the parent ligand and Fe(III) complex showed greater antioxidant capacity at low tested concentrations than that of other metal complexes where their $\mathrm{IC}_{50}$ were 169.7 and $164.6 \mu \mathrm{g} / \mathrm{mL}$, respectively.
\end{abstract}

Keywords: biological ligand; metal complexes; chelation theory; phytopathogens; human pathogens; antioxidants

\section{Introduction}

The crystal structures of several free fluoroquinolones molecules have been determined in several research [1-3]. It is interesting to note that in most cases the carboxylic group is not deprotonated and the hydrogen atom of this group is hydrogen bonded to an adjacent 4-oxo atom. In few examples such as gemifloxacin, lomefloxacin, norfloxacin, moxifloxacin, and 
ciprofloxacin, the carboxylic group is protonated and the molecules exist in a zwitterionic form with protonated terminal nitrogen of the piperazine ring in a solid state [4-6]. Crystal structures of fluoroquinolones complexes indicate that neutral fluoroquinolones in the zwitterionic state are capable of forming simple complexes bidentately through one of the carboxylic oxygen and ring carbonyl oxygen [7-10].

Gemifloxacin is the fourth generation of quinolones (or quinolonecarboxylic acids) that are an essential group of antibacterial agents containing 4-oxo-1,4-dihydroquinoline skeletons and are widely utilized in the medicament of many infections [11-13]. The addendum of the fluorine atom to the main quinolones produces fluoroquinolones, which have a much wider range of activity and improved pharmacokinetics [14-16]. Gemifloxacin is also an antibacterial drug with superior in vitro activity versus both Gram-positive $(\mathrm{G}+\mathrm{ve})$ and Gram-negative ( $\mathrm{G}$ - ve) bacteria $[17,18]$. Gemifloxacin is also reported to have an anticancer effect on colon cancer through metastasis inhibition [19]. It should be noted that gemifloxacin inhibits the action of DNA gyrase and topoisomerase IV, thus inhibiting DNA replication and eventually bacterial growth $[20,21]$. Gemifloxacin reacted with primary or secondary amine forming Schiff base [22-24]. Schiff bases are well-known to coordinate with most transition metal ions as a bidentate or tridentate, and their complexes are recorded [25]. In many areas, such as industrial, agricultural, and pharmaceutical chemistry, Schiff bases and their metal complexes have found vast applications [26-29]. In vision of the above consideration the current paper deals with the reaction of some elements such as Fe(III), $\mathrm{Co}(\mathrm{II}), \mathrm{Zn}(\mathrm{II})$, and $\mathrm{Zr}(\mathrm{IV})$ on the efficiency of gemifloxacin in the new form GMFX-o-phdn benzene-1,2-diamine [7 -[(4Z)-3(aminomethyl)-4-(methoxyimino) pyrrol dine-1-yl]-1-cyclopropyl-6-fluoro-4-oxo-1,8-naphthyridine-3-carboxylic acid]. The solid chelates were characterized using different physio-chemical techniques like elemental analyses (C, H, and N), IR, UV-Visible, ${ }^{1} \mathrm{H}$ NMR, molar conductance, magnetic susceptibility, melting points, thermo gravimetric (TG/DTG), and differential thermal (DTA) analyses. Moreover, the kinetic and thermodynamic parameters for the different thermal degradation steps of the compounds were determined by Coats-Redfern and HorowitzMetzger methods. The antifungal activity was evaluated against four phytopathogenic fungi: Monilinia fructicola (G. Winter) Honey, Aspergillus flavus Link, Penicillium italicum Wehmer, and Botrytis cinerea (de Bary) Whetzel. Whereas the antibacterial activity was evaluated against Escherichia coli Migula, Bacillus cereus Frankland \& Frankland, Pseudomonas fluorescens Flügge (Migula), and P. aeruginosa Schroter. Furthermore, the antiradical activity of the studied compounds was evaluated using 2,2'-azinobis (3-ethylbenzthiazoline-6-acid) (ABTS•+) assay.

\section{Results and Discussion}

\subsection{Physico and Chemical Characterization of GMFX-o-phdn and Its Complexes}

The elemental installation of the separated compounds in addition to their physical properties is shown in Table 1, which are in a decent concurrence with the proposed chemical formulae. The results acquired specified that all the isolated complexes were established by the reaction of metal ions and all the complexes reported here are hydrates with varying degrees of hydration with GMFX-o-phdn in a 1:1 molar ratio for all those metals. All complexes are stable in air, colored, non-hygroscopic powders, and soluble in DMSO and DMF. The molar conductance measurements of all the complexes in DMF solution were in the range of 173.10-272.40 $\Omega^{-1} \mathrm{~mol}^{-1} \mathrm{~cm}^{2}$ [30] [typified 1:3 electrolytic for (A) complex and 1:2 for (B), (C) and (D) complexes]. The relatively high values signalize electrolytic nature of the complexes which attributed to the non-bonding of the chloride anions to the metal ions in the inner coordination sphere $[17,30]$. The magnetic susceptibility measurements of the solid complexes were done at room temperature and the calculated values are shown in Table 1 . The magnetic moments of Fe(III) and $\mathrm{Co}(\mathrm{II})$ complexes were found at 5.81 and 5.10 B.M [31]. 
Table 1. Elemental analysis and physico-analytical data for (GMFX-o-phdn) and its metal complexes.

\begin{tabular}{|c|c|c|c|c|c|c|c|c|c|c|}
\hline \multirow{2}{*}{$\begin{array}{l}\text { Compounds } \\
\text { M.Wt. (M.F.) }\end{array}$} & \multirow{2}{*}{ Yield \% } & \multirow{2}{*}{$\mathrm{Mp} /{ }^{\circ} \mathrm{C}$} & \multirow{2}{*}{ Color } & \multicolumn{5}{|c|}{ Found (Calcd.) (\%) } & \multirow{2}{*}{$\underset{(B . M)}{\mu_{\text {eff }}}$} & \multirow{2}{*}{$\underset{\Omega^{-1} \mathrm{~mol}^{-1} \mathrm{~cm}^{2}}{\Lambda}$} \\
\hline & & & & $\mathrm{C}$ & $\mathbf{H}$ & $\mathbf{N}$ & $\mathbf{M}$ & $\mathrm{Cl}$ & & \\
\hline $\begin{array}{c}\text { (GMFX-o-phdn) } 1.5 \mathrm{H}_{2} \mathrm{O} 877.762 \\
\quad\left(\mathrm{C}_{42} \mathrm{H}_{47} \mathrm{~F}_{2} \mathrm{~N}_{12} \mathrm{O}_{7.5}\right)\end{array}$ & 80.00 & 190 & Dark red & $\begin{array}{l}57.29 \\
(57.41)\end{array}$ & $\begin{array}{c}5.26 \\
(5.35)\end{array}$ & $\begin{array}{c}19.02 \\
(19.13)\end{array}$ & & & & 17.60 \\
\hline $\begin{array}{c}(\mathrm{A}) \\
1138.957\left(\mathrm{FeC}_{42} \mathrm{H}_{58} \mathrm{~F}_{2} \mathrm{~N}_{12} \mathrm{O}_{13} \mathrm{Cl}_{3}\right)\end{array}$ & 82.00 & 290 & Brown & $\begin{array}{c}44.11 \\
(44.25) \\
\end{array}$ & $\begin{array}{c}5.00 \\
(5.09) \\
\end{array}$ & $\begin{array}{c}14.70 \\
(14.75)\end{array}$ & $\begin{array}{c}4.78 \\
(4.90) \\
\end{array}$ & $\begin{array}{l}9.23 \\
(9.33) \\
\end{array}$ & 5.81 & 272.40 \\
\hline 1106.592 $\left(\mathrm{CoC}_{42} \mathrm{H}_{58} \mathrm{~F}_{2} \mathrm{~N}_{12} \mathrm{O}_{13} \mathrm{Cl}_{2}\right)$ & 84.25 & 285 & Dark green & $\begin{array}{c}45.40 \\
(45.54)\end{array}$ & $\begin{array}{c}5.18 \\
(5.24)\end{array}$ & $\begin{array}{c}15.10 \\
(15.18)\end{array}$ & $\begin{array}{c}5.12 \\
(5.32)\end{array}$ & $\begin{array}{l}6.29 \\
(6.40)\end{array}$ & 5.10 & 173.10 \\
\hline $\begin{array}{c}(\mathrm{C}) \\
1131.042\left(\mathrm{ZnC}_{42} \mathrm{H}_{60} \mathrm{~F}_{2} \mathrm{~N}_{12} \mathrm{O}_{14} \mathrm{Cl}_{2}\right)\end{array}$ & 86.10 & 270 & $\begin{array}{c}\text { Dark } \\
\text { brown }\end{array}$ & $\begin{array}{c}44.41 \\
(44.56)\end{array}$ & $\begin{array}{c}5.11 \\
(5.30)\end{array}$ & $\begin{array}{c}14.76 \\
(14.85) \\
\end{array}$ & $\begin{array}{c}5.70 \\
(5.78)\end{array}$ & $\begin{array}{l}6.13 \\
(6.26) \\
\end{array}$ & & 176.20 \\
\hline 1136.886 $\left(\mathrm{ZrC}_{42} \mathrm{H}_{56} \mathrm{~F}_{2} \mathrm{~N}_{12} \mathrm{O}_{13} \mathrm{Cl}_{2}\right)$ & 87.15 & 300 & Black & $\begin{array}{c}44.26 \\
(44.33)\end{array}$ & $\begin{array}{c}4.81 \\
(4.92)\end{array}$ & $\begin{array}{c}14.60 \\
(14.77)\end{array}$ & $\begin{array}{c}7.96 \\
(8.02)\end{array}$ & $\begin{array}{l}6.14 \\
(6.23)\end{array}$ & & 175.30 \\
\hline
\end{tabular}

\subsection{IR Spectra and Mode of Bonding}

Careful implementing of the IR spectra of complexes and rapprochement with that of the ligand were executed to find out donation information to clarify the technique of bonding of the ligand across diverse metal ions. Thus, a deliberated implementing of the IR spectrum of the ligand was performed and the effectiveness of the metal ion binding in the vibration frequencies was analyzed. The most substantial IR spectral bands of all systems and their assignments are collected in Table 2 and their spectra are offered in Figure S1. The data educe the following observations: the GMFX-o-phdn infrared spectrum reveals the obscurity of bands due to the o-phenylenediamine group $v\left(\mathrm{NH}_{2}\right)$ and $v(\mathrm{C}=\mathrm{O})$ of gemifloxacin. Instead, newly formed very strong band at $1633 \mathrm{~cm}^{-1}$ is obtained showing the complete condensation of the amino groups with the keto group demonstrating the development of the linkage of the Schiff base $[32,33]$.

Table 2. Selected infrared absorption frequencies $\left(\mathrm{cm}^{-1}\right)$ for GMFX-o-phdn and its metal complexes.

\begin{tabular}{|c|c|c|c|c|c|c|c|}
\hline Compounds & $\begin{array}{c}v(\mathrm{O}-\mathrm{H}) ; \mathrm{H}_{2} \mathrm{O} ; \\
\mathrm{COOH}\end{array}$ & $\begin{array}{l}v(\mathrm{C}=\mathrm{O}) \\
\mathrm{COOH}\end{array}$ & $v_{\mathrm{as}}\left(\mathrm{COO}^{-}\right)$ & $v(\mathrm{C}=\mathrm{N})$ & $v_{\mathrm{s}}\left(\mathrm{COO}^{-}\right)$ & $v(\mathrm{Zr}=\mathrm{O})$ & $v(\mathrm{M}-\mathrm{O}), v(\mathrm{M}-\mathrm{N})$ \\
\hline GMFX-o-phdn & $3427 \mathrm{mbr}$ & $1715 \mathrm{~s}$ & - & $1633 \mathrm{~s}$ & & - & $635 \mathrm{w}$ and $548 \mathrm{~m}$ \\
\hline (A) & 3436 sbr & - & $1635 \mathrm{vs}$ & $1573 \mathrm{~m}$ & - & - & $639 \mathrm{w}$ and $492 \mathrm{w}$ \\
\hline (B) & $3434 \mathrm{mbr}$ & - & $1635 \mathrm{vs}$ & $1570 \mathrm{~m}$ & $1391 \mathrm{w}$ & - & $638 \mathrm{~m}$ and $500 \mathrm{w}$ \\
\hline (C) & $3432 \mathrm{sbr}$ & - & $1634 \mathrm{vs}$ & $1578 \mathrm{~s}$ & $1387 \mathrm{w}$ & - & $637 \mathrm{~m}$ and $536 \mathrm{~m}$ \\
\hline (D) & 3432 sbr & - & $1638 v s$ & $1528 \mathrm{~m}$ & $1360 \mathrm{~m}$ & $813 \mathrm{~m}$ & $640 \mathrm{~m}$ and $497 \mathrm{w}$ \\
\hline
\end{tabular}

Keys: $\mathrm{s}=$ strong, $\mathrm{w}=$ weak, $\mathrm{m}=$ medium, $\mathrm{br}=$ broad, $\mathrm{v}=$ stretching.

The IR spectra of all complexes containing hydration and coordination water molecules display bands around $3434 \mathrm{~cm}^{-1}$ due to $v(\mathrm{O}-\mathrm{H})$ vibration mode of the water molecules which is also supported by elemental analyses [34,35]. Moreover, the appearance of bands around 840 , and $600 \mathrm{~cm}^{-1}$ in the spectra of all complexes were attributed to rocking and wagging vibration of the coordinated water $[36,37]$. The two bands spotted at 1715 and $1633 \mathrm{~cm}^{-1}$ in the spectrum of GMFX-o-phdn were referred to the stretching vibration of carboxylic $v(\mathrm{COOH})$ and the azomethine group $v(\mathrm{C}=\mathrm{N})$, respectively [36-38]. The missing of the band at $1715 \mathrm{~cm}^{-1}$ in all complexes and the shift of the distinctive band of azomethine group to a lower value from $1633 \mathrm{~cm}^{-1}$ to $1528 \mathrm{~cm}^{-1}$ specified the participation of one oxygen of the carboxylate group and $\mathrm{C}=\mathrm{N}$ group in the interaction with metal ion forming six-membered rings (Scheme 1) [35]. The bonding is also reinforced by the occurrence of new bands with medium intensity appearing at $640-492 \mathrm{~cm}^{-1}$ which assigned to $v(\mathrm{M}-\mathrm{O})$ and $v(\mathrm{M}-\mathrm{N})$ stretching vibrations, respectively [38]. 


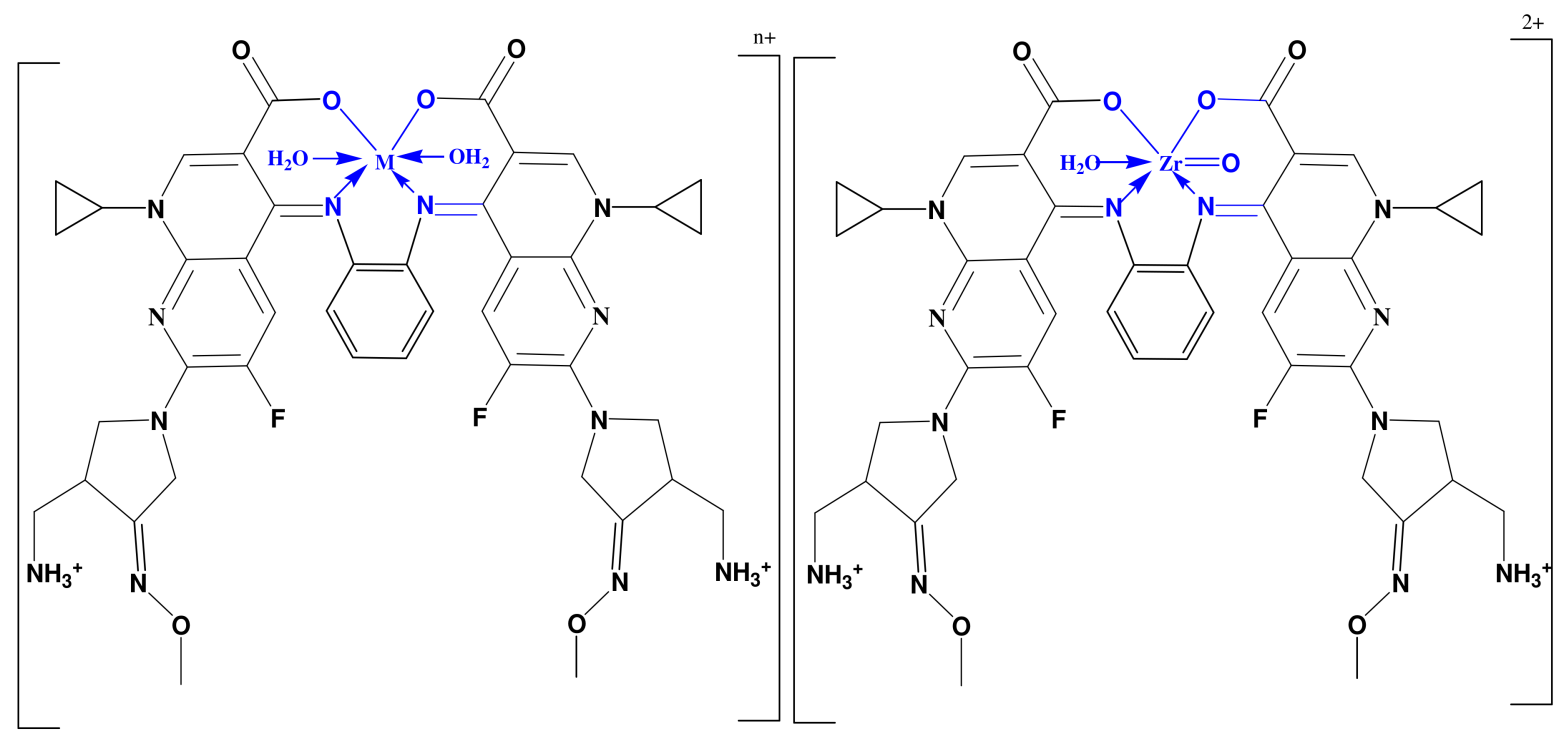

Scheme 1. Coordination mode of GMFX-o-phdn with Fe(III), Co(II), Zn(II), and Zr(IV) $n=3$ for $\mathrm{Fe}(\mathrm{III})$ and $n=2$ for $\mathrm{Co}(\mathrm{II}), \mathrm{Zn}(\mathrm{II})$.

\subsection{UV-Vis Absorption Spectra}

The electronic spectral data are often useful in the estimation of results provided by other methods of structural examination. The assignments of the important electronic spectral bands (Figure S2) of ligand and its metal ion complexes are shown in Table 3. Assorted bands in the electronic spectra of GMFX-o-phdn demonstrated bands at 33,898 and $31,746 \mathrm{~cm}^{-1}$ (Table 3 ) which may be assigned to $\pi-\pi^{*}$ and $n-\pi^{*}$ transitions, respectively; these transitions take place in the condition of unsaturated hydrocarbons containing groups of ketones or groups of azomethine [39,40]. The complexes exhibited new bands in the range of 22,222-20,408 $\mathrm{cm}^{-1}$, which may be attributed to a combination of ligand-metal charge transfer (MLCT) [41]. The electronic spectrum of (A) complex shows absorption band at $17,241 \mathrm{~cm}^{-1}$ corresponding to ${ }^{6} \mathrm{~A}_{1}-{ }^{4} \mathrm{~T}_{2}(\mathrm{G})$ transitions and the spotted magnetic moment value at 5.81 B.M, suggesting the complex's high octahedral spin [38,42]. The electronic spectrum of $\mathrm{Co}(\mathrm{II})$ complex, $\left[\mathrm{CoC}_{42} \mathrm{H}_{58} \mathrm{~F}_{2} \mathrm{~N}_{12} \mathrm{O}_{13} \mathrm{Cl}_{2}\right.$ ] (Figure S2), shows recognizable bands at 18,181 and $16,949 \mathrm{~cm}^{-1}$; the presence of these bands are consistent with those expected for six coordinate $\mathrm{Co}(\mathrm{II})$ complex [43]. These bands can be assigned respectively to ${ }^{4} \mathrm{~T}_{1 \mathrm{~g}}(\mathrm{~F})$ $\rightarrow{ }^{4} \mathrm{~T}_{1 \mathrm{~g}}(\mathrm{P})$ and ${ }^{4} \mathrm{~T}_{1 \mathrm{~g}}(\mathrm{~F}) \rightarrow{ }^{4} \mathrm{~T}_{1 \mathrm{~g}}(\mathrm{~F})$ transitions $[44,45]$. Molar absorptivity $(\varepsilon)$ obtained from the electronic spectra of complexes were recorded by using the relation: $A=\varepsilon c l$, where $\mathrm{A}=$ absorbance, $\mathrm{c}=1 \times 10^{-3} \mathrm{M}, 1=$ length of cell $(1 \mathrm{~cm})[46]$.

Table 3. UV-Vis. spectra for GMFX-o-phdn and its metal complexes.

\begin{tabular}{|c|c|c|c|c|}
\hline Compounds & $\begin{array}{l}\text { Intra Ligand and } \\
\text { Charge Transfer }\end{array}$ & $\left(M^{-1} \mathrm{~cm}^{-1}\right)$ & d-d Bands & $\left(M^{-1} \mathrm{~cm}^{-1}\right)$ \\
\hline GMFX-o-phdn & $33,898,31,746$ & 452,155 & & \\
\hline$(\mathrm{A})$ & $34,129,30,769,22,222$ & $453,158,100$ & 17,241 & 70 \\
\hline (B) & $34,246,31,250,20,408$ & $453,155,80$ & $18,181,16,949$ & 60,50 \\
\hline (C) & $34,246,30,769,21,276$ & $452,160,67$ & & \\
\hline (D) & $34,129,30,769,20,408$ & $452,172,69$ & & \\
\hline
\end{tabular}

\section{4. ${ }^{1} \mathrm{H}$ NMR Spectra}

The ${ }^{1} \mathrm{H}-\mathrm{NMR}$ spectra of GMFX-o-phdn, $\mathrm{Zn}(\mathrm{II})$ and $\mathrm{Zr}(\mathrm{IV})$ compounds were acquired by dissolving them in DMSO-d6 and employing TMS as internal standard Figure S3. The chemical shifts of the diverse types of protons of GMFX-o-phdn, $\mathrm{Zn}$ (II) and $\mathrm{Zr}$ (IV) compounds were registered in Table $4 .{ }^{1} \mathrm{H}$ NMR of Schiff base GMFX-o-phdn (DMSO-d6): 
$\delta(1.10-1.34)(1,2))\left(\mathrm{m}, J=0.72,4 \mathrm{H},-\mathrm{CH}_{2}\right.$ cyclopropane), $1.82(3)(\mathrm{m}, J=5.46,1 \mathrm{H},-\mathrm{CH}$ cyclopropane), $2.32(-\mathrm{NH})\left(\mathrm{s}, J=6.96,2 \mathrm{H},-\mathrm{NH}_{2}\right), 2.50-2.52(8)\left(\mathrm{d}, J=0.06,2 \mathrm{H},-\mathrm{CH}_{2}\right.$ amine methylene) 3.14- $3.20(10)\left(\mathrm{s}, 2 \mathrm{H}, J=0.18,-\mathrm{CH}_{2}\right.$ methylene), $3.82\left(\mathrm{~s}, J=11.46,2 \mathrm{H}, \mathrm{H}_{2} \mathrm{O}\right)$, 4.37-4.57 (9) (s, $J=0.6,3 \mathrm{H},-\mathrm{CH}_{3}$ methyl), 6.90-8.59 (4,5) (s, J = 5.07, 2H, $\left.\mathrm{H}_{\mathrm{Ar}}\right)$ [26]. The signal at $11 \mathrm{ppm}(\mathrm{COOH})$ in the spectrum of the ligand was not registered in $\mathrm{Zn}(\mathrm{II})$ and $\mathrm{Zr}(\mathrm{IV})$ complexes indicating displacement and complexation of the GMFX-o-phdn with metal ions [41]. Furthermore, the ${ }^{1} \mathrm{H}$ NMR spectra for complexes demonstrate a new peak in $\mathrm{Zn}(\mathrm{II})$ and $\mathrm{Zr}(\mathrm{IV})$ complexes at 3.45 and $3.50 \mathrm{ppm}$, due to the existence of water molecules in the complexes. All peaks of the GMFX-o-phdn are sitting in spectra of the complexes with some shifts from binding of GMFX-o-phdn to the metal ions [47].

Table 4. ${ }^{1} \mathrm{H}$ NMR values (ppm) and tentative assignments for GMFX-o-phdn, (C) and (D) metal complexes.

\begin{tabular}{cccc}
\hline GMFX-o-phdn & (C) & (D) & Assignments \\
\hline $1.10-1.34$ & $1.23-1.30$ & $1.28-1.36$ & $\delta \mathrm{H},-\mathrm{CH}_{2}$ cyclopropane \\
1.82 & 1.61 & 1.90 & $\delta \mathrm{H},-\mathrm{CH}$ cyclopropane \\
2.32 & 2.14 & 2.15 & $\delta \mathrm{H},-\mathrm{NH}_{2}$; piperazine \\
$2.50-2.52$ & $2.31-2.90$ & $2.32-2.88$ & $\delta \mathrm{H}_{-}-\mathrm{CH}_{2}$, amine methylene \\
$3.14-3.20$ & 3.21 & 3.19 & $\delta \mathrm{H}_{2}-\mathrm{CH}_{2}$, methylene \\
3.82 & 3.45 & 3.50 & $\delta \mathrm{H}_{2} \mathrm{O}$ \\
$4.37-4.57$ & 4.10 & $4.12-4.22$ & $\delta \mathrm{H}_{2},-\mathrm{CH}_{3}$ methyl \\
$6.90-8.59$ & $7.07-8.50$ & $6.89-8.52$ & $\delta \mathrm{H},-\mathrm{CH}$ aromatic \\
11 & - & & $\delta \mathrm{H},-\mathrm{COOH}$ \\
\hline
\end{tabular}

\subsection{Thermal Studies (TG and DTG)}

TG and DTG analyses were performed for affirmation of the molecular structure of the complexes, their thermal stabilities, and revelation of the diverse types of solvents of crystallization. The temperature ranges and weight losses together with DTG peaks are indexed in Table 5 and showed in Figure S4. All synthesized compounds are subjected to thermo gravimetric analysis within temperature range from $25^{\circ} \mathrm{C}$ to $1000{ }^{\circ} \mathrm{C}$ in nitrogen. The GMFX-o-phdn was thermally decomposed in two sequential decomposition steps. The first and second steps with estimated mass loss of $98.40 \%$ (calculated mass loss = $98.65 \%$ ) within the temperature ranges $32-114{ }^{\circ} \mathrm{C}$ and $114-810{ }^{\circ} \mathrm{C}$ may be attributed to the loss of $1.5 \mathrm{H}_{2} \mathrm{O}$ and $18 \mathrm{C}_{2} \mathrm{H}_{2}+2 \mathrm{HF}+2 \mathrm{NH}_{3}+2 \mathrm{C}_{2} \mathrm{~N}_{2}+\mathrm{CO}_{2}+2 \mathrm{NO}_{2}+2 \mathrm{~N}_{2}$. The TG curve of complex (A) has three degradation steps, the first one has $7.87 \%$ weight loss (calculated weight loss $=7.91 \%$ ) in the range $33{ }^{\circ} \mathrm{C}$ to $133{ }^{\circ} \mathrm{C}$, indicating the removal of five hydrated water molecules. The second step with weight loss $37.20 \%$ (calc $=37.40 \%$ ) at maximum temperature $203{ }^{\circ} \mathrm{C}$ supporting the removal of two coordinating $\mathrm{H}_{2} \mathrm{O}$ and $15 \mathrm{C}_{2} \mathrm{H}_{2}$ molecules. The third step with two maxima at $317^{\circ} \mathrm{C}, 435^{\circ} \mathrm{C}$ with $42.80 \%$ weight loss (calc: $42.42 \%$ ), corresponding to the removal of $3 \mathrm{C}_{2} \mathrm{H}_{2}+3 \mathrm{HCl}+2 \mathrm{HF}+\mathrm{CO}+2 \mathrm{NH}_{3}$ $+1.5 \mathrm{H}_{2} \mathrm{O}+2 \mathrm{NO}+\mathrm{N}_{2}$ molecules and forming $0.5 \mathrm{Fe}_{2} \mathrm{O}_{3}$ and five carbon as residue. TG thermograms of the three solid complexes (B), (C), and (D) showed three decomposition steps. The first step occurs at $67,113,62$, and $74{ }^{\circ} \mathrm{C}$ maxima temperatures, respectively, with the mass loss of $8.10 \%, 9.50 \%$, and $7.90 \%$ corresponding to the loss of lattice water. The second step occurs at 212,326 , and $172{ }^{\circ} \mathrm{C}$ maxima temperatures, respectively, with the weight loss $38.20 \%, 30.70 \%$, and $23.70 \%$ corresponding to the loss of $15 \mathrm{C}_{2} \mathrm{H}_{2}+2 \mathrm{H}_{2} \mathrm{O}$, $12 \mathrm{C}_{2} \mathrm{H}_{2}+2 \mathrm{H}_{2} \mathrm{O}$, and $9 \mathrm{C}_{2} \mathrm{H}_{2}+2 \mathrm{H}_{2} \mathrm{O}$ for (B), (C), and (D) complexes. The third step with $436,394,366$, and $448{ }^{\circ} \mathrm{C}$ maxima temperatures, respectively, with a weight loss $41.17 \%$, $47.80 \%$, and $53.40 \%$ giving $\mathrm{CoO}+5 \mathrm{C}, \mathrm{ZnO}+4 \mathrm{C}$, and $\mathrm{ZrO} 2+4 \mathrm{C}$ as final products. The decomposition mechanisms are only based in speculation and thermal analysis without a complementary technique (gas chromatography). The suggested residues confirmed only on the basis of weight loss\% calculation. 
Table 5. The maximum temperature $\mathrm{T}_{\max }\left({ }^{\circ} \mathrm{C}\right)$ and weight loss values of the decomposition stages for GMFX-o-phdn and its metal complexes.

\begin{tabular}{|c|c|c|c|c|c|c|}
\hline \multirow{2}{*}{ Compounds } & \multirow{2}{*}{ Decomposition } & \multirow{2}{*}{$\begin{array}{c}\text { Temperature } \\
\text { Range }\left({ }^{\circ} \mathrm{C}\right)\end{array}$} & \multirow{2}{*}{$\mathrm{T}_{\max }\left({ }^{\circ} \mathrm{C}\right)$} & \multicolumn{2}{|c|}{ Weight Loss (\%) } & \multirow{2}{*}{ Lost Species } \\
\hline & & & & Calc. & Found & \\
\hline \multirow{4}{*}{$\begin{array}{c}\left(\mathrm{GMFX}-\mathrm{o}^{-}\right. \\
\text {phdn) } 1.5 \mathrm{H}_{2} \mathrm{O}\end{array}$} & First step & $32-114$ & 82 & 3.08 & 3.10 & \multirow{4}{*}{$\begin{array}{c}1.5 \mathrm{H}_{2} \mathrm{O} \\
18 \mathrm{C}_{2} \mathrm{H}_{2}+2 \mathrm{HF}+2 \mathrm{NH}_{3}+2 \mathrm{C}_{2} \mathrm{~N}_{2}+\mathrm{CO}_{2}+ \\
2 \mathrm{NO}_{2}+2 \mathrm{~N}_{2}\end{array}$} \\
\hline & Second step & $114-1000$ & $188,293,386$ & 95.56 & 95.30 & \\
\hline & Total loss & & & 98.65 & 98.40 & \\
\hline & Residue & & & 1.36 & 1.60 & \\
\hline \multirow{5}{*}{ (A) } & First step & $33-133$ & 90,118 & 7.91 & 7.87 & \multirow{5}{*}{$\begin{array}{c}5 \mathrm{H}_{2} \mathrm{O} \text { (lattice) } \\
15 \mathrm{C}_{2} \mathrm{H}_{2}+2 \mathrm{H}_{2} \mathrm{O} \text { (coordinated) } \\
3 \mathrm{C}_{2} \mathrm{H}_{2}+3 \mathrm{HCl}+2 \mathrm{HF}+\mathrm{CO}+2 \mathrm{NH}_{3}+ \\
1.5 \mathrm{H}_{2} \mathrm{O}+2 \mathrm{NO}+\mathrm{N}_{2}\end{array}$} \\
\hline & Second step & $133-241$ & 203 & 37.40 & 37.20 & \\
\hline & Third step & \multirow[t]{3}{*}{$241-950$} & \multirow[t]{3}{*}{317,435} & 42.42 & 42.80 & \\
\hline & Total loss & & & 87.73 & 87.87 & \\
\hline & Residue & & & 12.27 & 12.13 & \\
\hline \multirow{5}{*}{ (B) } & First step & $32-131$ & 67,113 & 8.13 & 8.10 & \multirow{5}{*}{$\begin{array}{c}5 \mathrm{H}_{2} \mathrm{O} \text { (lattice) } \\
15 \mathrm{C}_{2} \mathrm{H}_{2}+2 \mathrm{H}_{2} \mathrm{O} \text { (coordinated) } \\
3 \mathrm{C}_{2} \mathrm{H}_{2}+2 \mathrm{HCl}+2 \mathrm{HF}+\mathrm{CO}+2 \mathrm{NO}_{2}+ \\
2 \mathrm{H}_{2}+5 \mathrm{~N}_{2} \\
\mathrm{CoO}+5 \mathrm{C}\end{array}$} \\
\hline & Second step & $131-256$ & 212 & 38.49 & 38.20 & \\
\hline & Third step & $256-850$ & 436 & 41.19 & 41.17 & \\
\hline & Total loss & & & 87.81 & 87.47 & \\
\hline & Residue & & & 12.19 & 12.53 & \\
\hline \multirow{5}{*}{ (C) } & First step & $32-134$ & 62 & 9.55 & 9.50 & \multirow{5}{*}{$\begin{array}{c}6 \mathrm{H}_{2} \mathrm{O} \text { (lattice) } \\
12 \mathrm{C}_{2} \mathrm{H}_{2}+2 \mathrm{H}_{2} \mathrm{O} \text { (coordinated) } \\
6 \mathrm{C}_{2} \mathrm{H}_{2}+\mathrm{C}_{2} \mathrm{~N}_{2}+2 \mathrm{HF}+2 \mathrm{HCl}+2 \mathrm{H}_{2}+ \\
5 \mathrm{~N}_{2} \\
\mathrm{ZnO}+4 \mathrm{C}\end{array}$} \\
\hline & Second step & $134-331$ & 326 & 30.77 & 30.70 & \\
\hline & Third step & $331-870$ & 394 & 48.24 & 47.80 & \\
\hline & Total loss & & & 88.56 & 88.00 & \\
\hline & Residue & & & 11.44 & 12.00 & \\
\hline \multirow{5}{*}{ (D) } & First step & $32-131$ & 74 & 7.92 & 7.90 & \multirow{5}{*}{$\begin{array}{c}5 \mathrm{H}_{2} \mathrm{O} \text { (lattice) } \\
9 \mathrm{C}_{2} \mathrm{H}_{2}+2 \mathrm{H}_{2} \mathrm{O} \text { (coordinated) } \\
10 \mathrm{C}_{2} \mathrm{H}_{2}+2 \mathrm{HCl}+2 \mathrm{HF}+2 \mathrm{NO}_{2}+5 \mathrm{~N}_{2} \\
\mathrm{ZrO}_{2}+4 \mathrm{C}\end{array}$} \\
\hline & Second step & $131-273$ & 172 & 23.75 & 23.70 & \\
\hline & Third step & $273-970$ & 366,448 & 53.27 & 53.40 & \\
\hline & Total loss & & & 84.94 & 85.00 & \\
\hline & Residue & & & 15.06 & 15.00 & \\
\hline
\end{tabular}

\subsection{Differential Thermal Analysis (DTA)}

According to the prior DTA survey, the DTA nitrogen thermogram of GMFX-o-phdn with metal complexes under study offers several phases, as shown in Figure 1. In the DTA curves, the chemical modifications that follow the removal of water, anion, and ligand molecules are spotted as exo- or endothermic peaks. At 88, 189, 282, and $439{ }^{\circ} \mathrm{C}$, the GMFX-o-phdn offers these four peaks. The peaks 88,282 , and $439^{\circ} \mathrm{C}$ are endothermic peaks with $-4.77,-0.35$, and $-0.55 \mu \mathrm{V}$, respectively, except $189^{\circ} \mathrm{C}$ is exothermic peak with $11.01 \mu \mathrm{V}$ with this activation energy. The (A) complex has severalpeaks (endothermic and exothermic) of $1.20,2.51$, and $-0.63 \mu \mathrm{V}$ activation energies at different temperatures of 137,203 , and $328^{\circ} \mathrm{C}$ respectively. The complex (B) manifested three peaks at 72,119 , and $329^{\circ} \mathrm{C}$ for A. Evaporation of absorbed water is imputed to the first and second peaks and well-defined as endothermic peaks at 72 and $119^{\circ} \mathrm{C}$ and activation energy of $-3.24 \mu \mathrm{V}$ and $-0.99 \mu \mathrm{V}$. At $329^{\circ} \mathrm{C}$, the third peak reflects $-1.39 \mu \mathrm{V}$ of decomposition and activation energy. DTA curve of (C) complex manifests two peaks at 67 and $395^{\circ} \mathrm{C}$. The first endothermic peak with activation energy of $-3.84 \mu \mathrm{V}$ at $67^{\circ} \mathrm{C}$ matched to lack of water molecules hydration and the last peak at $395^{\circ} \mathrm{C}$ matched to the abstraction of coordinated water and GMFX-o-phdn molecules with activation energy of $-0.53 \mu \mathrm{V}$. Finally, DTA curve of (D) complex presented four peaks at $80,197,331$, and $448^{\circ} \mathrm{C}$. The first endothermic peak with activation energy of $-4.36 \mu \mathrm{V}$ at $80^{\circ} \mathrm{C}$ matched to lack of water molecules hydration and the last three peaks at 197,331 , and $448^{\circ} \mathrm{C}$ matched to the abstraction of coordinated water and Schiff base GMFX-o-phdn molecules with activation energies of 1.50, -1.92 , and $-1.49 \mu \mathrm{V}$. 

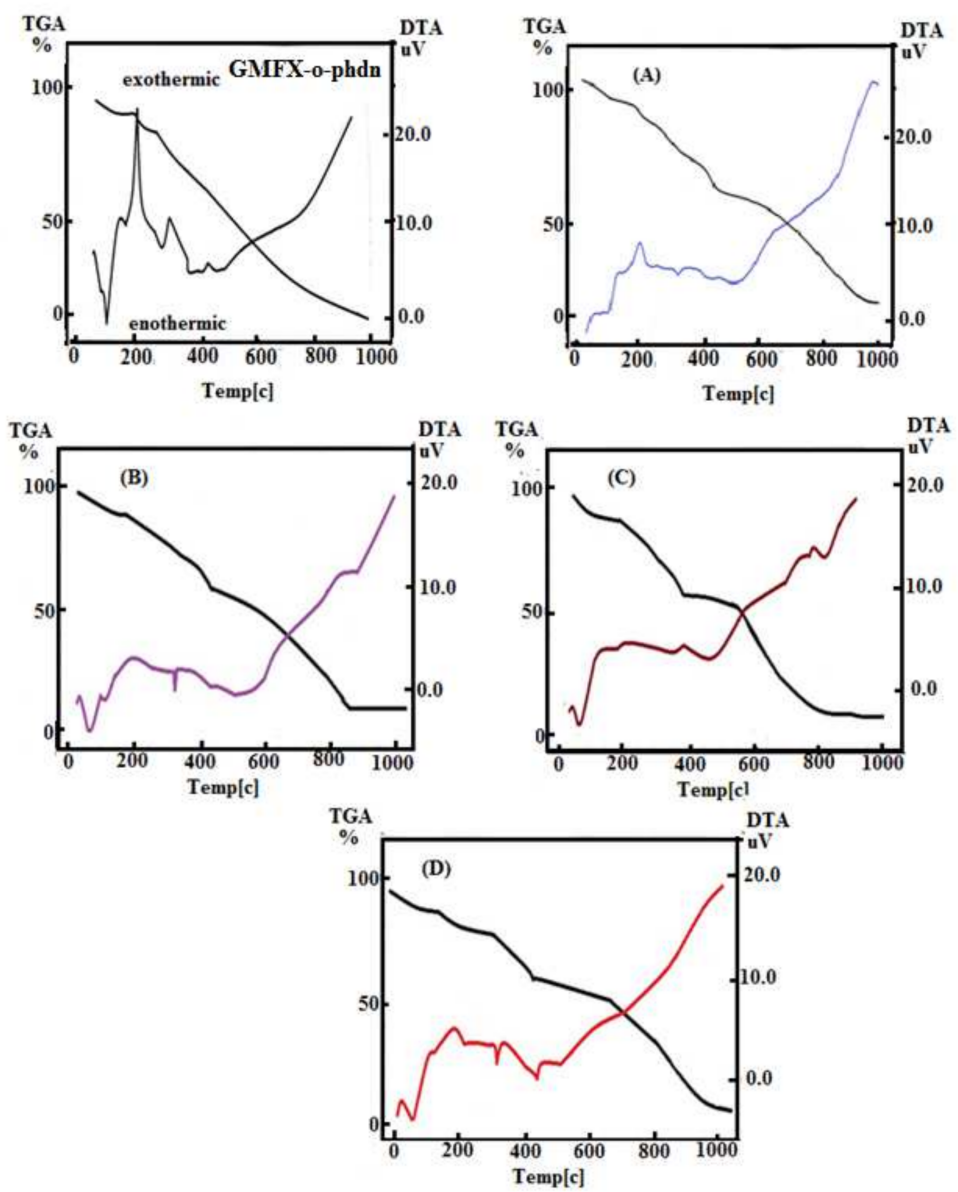

Figure 1. DTA diagram for GMFX-o-phdn and its metal complexes. Where: TGA and DTA are thermo gravimetric and differential thermal analyses, respectively; (A) $\mathrm{FeC}_{42} \mathrm{H}_{58} \mathrm{~F}_{2} \mathrm{~N}_{12} \mathrm{O}_{13} \mathrm{Cl}_{3}$ complex; (B) $\mathrm{CoC}_{42} \mathrm{H}_{58} \mathrm{~F}_{2} \mathrm{~N}_{12} \mathrm{O}_{13} \mathrm{Cl}_{2}$ complex; (C) $\mathrm{ZnC}_{42} \mathrm{H}_{60} \mathrm{~F}_{2} \mathrm{~N}_{12} \mathrm{O}_{14} \mathrm{Cl}_{2}$ complex; and (D) $\mathrm{ZrC}_{42} \mathrm{H}_{56} \mathrm{~F}_{2} \mathrm{~N}_{12} \mathrm{O}_{13} \mathrm{Cl}_{2}$ complex.

\subsection{Calculation of Activation Thermodynamic Parameters}

Kinetic parameters of the decomposition steps were specified by non-isothermal approaches such as Horowitz-Metzger (HM) and Coats-Redfern (CR) methods [48,49].

Coats-Redfern equation:

$$
\begin{gathered}
\ln X=\ln \left[\frac{-\ln (1-\alpha)}{\mathrm{T}^{2}}\right]=\frac{-\mathrm{Ea}}{\mathrm{RT}}+\ln \left[\frac{\mathrm{AR}}{\varphi \mathrm{Ea}}\right] \text { for } n=1 . \\
\ln X=\ln \left[\frac{-\ln (1-\alpha)^{1-n}}{\mathrm{~T}^{2}(1-n)}\right]=\frac{-\mathrm{Ea}}{\mathrm{RT}}+\ln \left[\frac{\mathrm{AR}}{\varphi \mathrm{Ea}}\right] \text { for } n \neq 1 .
\end{gathered}
$$

Horowitz-Metzger equation:

$$
\begin{gathered}
\ln [-\ln (1-\alpha)]=\frac{\mathrm{E}_{\mathrm{a}} \theta}{\mathrm{RT}_{\mathrm{s}}^{2}} \text { for } n=1 \\
\ln \left[\frac{\left\{1-(1-\alpha)^{1-n}\right\}}{(1-n)}\right]=\ln \left(\frac{\mathrm{A}}{\Phi} \frac{\mathrm{RT}_{\mathrm{s}}^{2}}{\mathrm{Ea}}\right)-\frac{\mathrm{E}_{\mathrm{a}}}{\mathrm{RT}_{\mathrm{s}}}+\frac{\mathrm{E}_{\mathrm{a}} \theta}{\mathrm{RT}_{\mathrm{s}}^{2}} \text { for } n \neq 1
\end{gathered}
$$

The higher activation energy (Ea) values represent the thermal stability of the complexes and are summarized in Table 6. For the subsequent decomposition phases, the increase of the $\Delta \mathrm{G}^{*}$ value implies that the rate of elimination of the GMFX-o-phdn would 
be less than that of the prior GMFX-o-phdn and the increase of $\mathrm{T} \Delta \mathrm{S}^{*}$ from one phase to another, Figure S5. Compared to the previous complex that needs more energy, $\mathrm{T} \Delta \mathrm{S}^{*}$, this can be due to the structural rigidity of the residual complex following exclusion of one or more GMFX-o-phdn for its rearrangement before undergoing any modulation. Entropy has been shown to have negative numbers in all complexes, which further proposed their stability [50]. The positive value of $\Delta \mathrm{H}^{*}$ imply that the decay is endothermic.

Table 6. Thermal behavior and Kinetic parameters determined using Coats-Redfern (CR) and Horowitz-Metzger (HM) operated for GMFX-o-phdn and its metal complexes.

\begin{tabular}{|c|c|c|c|c|c|c|c|c|c|c|}
\hline \multirow[b]{2}{*}{ Compounds } & \multirow{2}{*}{$\begin{array}{l}\text { Decomposition } \\
\text { Range (K) }\end{array}$} & \multirow{2}{*}{$\begin{array}{l}\mathbf{T}_{\mathbf{s}} \\
(\mathrm{K})\end{array}$} & \multirow[b]{2}{*}{ Method } & \multicolumn{5}{|c|}{ Parameters } & \multirow[b]{2}{*}{$\mathbf{R}^{\mathbf{a}}$} & \multirow[b]{2}{*}{$S^{b}$} \\
\hline & & & & $\begin{array}{c}\text { Ea } \\
(\mathrm{KJ} / \mathrm{mol})\end{array}$ & $\underset{\left(s^{-1}\right)}{A}$ & $\begin{array}{c}\Delta \mathrm{S}^{*} \\
(\mathrm{KJ} / \mathrm{mol} . \mathrm{K})\end{array}$ & $\begin{array}{c}\Delta \mathrm{H}^{*} \\
(\mathrm{KJ} / \mathrm{mol})\end{array}$ & $\begin{array}{c}\Delta \mathrm{G}^{*} \\
(\mathrm{KJ} / \mathrm{mol})\end{array}$ & & \\
\hline \multirow{8}{*}{$\begin{array}{l}\text { GMFX-o- } \\
\text { phdn }\end{array}$} & \multirow{2}{*}{$305-387$} & \multirow{2}{*}{355} & CR & 74.28 & $2.88 \times 10^{8}$ & -0.0101 & 71.33 & 74.94 & 0.978 & 0.155 \\
\hline & & & HM & 84.18 & $3.25 \times 10^{10}$ & -0.0450 & 81.23 & 97.24 & 0.974 & 0.168 \\
\hline & \multirow{2}{*}{$387-506$} & \multirow{2}{*}{387} & CR & 98.54 & $1.54 \times 10^{10}$ & -0.0520 & 98.98 & 119.10 & 0.978 & 0.157 \\
\hline & & & $\mathrm{HM}$ & 99.61 & $3.70 \times 10^{11}$ & -0.0256 & 96.39 & 106.30 & 0.974 & 0.168 \\
\hline & \multirow{2}{*}{$496-635$} & \multirow{2}{*}{566} & CR & 125.77 & $5.88 \times 10^{9}$ & -0.0632 & 121.06 & 121.07 & 0.960 & 0.201 \\
\hline & & & $\mathrm{HM}$ & 154.00 & $1.56 \times 10^{12}$ & -0.0167 & 149.29 & 158.79 & 0.962 & 0.215 \\
\hline & \multirow{2}{*}{$635-1273$} & \multirow{2}{*}{659} & CR & 107.79 & $4.00 \times 10^{5}$ & -0.0173 & 102.31 & 113.75 & 0.963 & 0.262 \\
\hline & & & HM & 101.99 & $5.70 \times 10^{5}$ & -0.1413 & 96.52 & 189.64 & 0.953 & 0.297 \\
\hline \multirow{8}{*}{ (A) } & \multirow{2}{*}{$306-406$} & \multirow{2}{*}{363} & CR & 26.71 & 8.321 & -0.2289 & 23.69 & 106.78 & 0.998 & 0.0137 \\
\hline & & & $\mathrm{HM}$ & 30.80 & 0.0046 & -0.2911 & 27.78 & 133.48 & 0.997 & 0.0181 \\
\hline & \multirow{2}{*}{$406-514$} & \multirow{2}{*}{391} & CR & 21.92 & 0.7427 & -0.2496 & 18.67 & 116.27 & 0.999 & 0.0038 \\
\hline & & & HM & 22.85 & 0.0029 & -0.2955 & 19.60 & 135.14 & 0.999 & 0.0064 \\
\hline & \multirow{2}{*}{$514-637$} & \multirow{2}{*}{476} & CR & 29.57 & 1.1254 & -0.2478 & 25.61 & 143.57 & 0.999 & 0.0016 \\
\hline & & & $\mathrm{HM}$ & 25.97 & 1.6232 & -0.2447 & 22.01 & 138.52 & 0.999 & 0.0031 \\
\hline & \multirow{2}{*}{$514-637$} & \multirow{2}{*}{590} & CR & 32.43 & 0.8072 & -0.2523 & 27.53 & 176.42 & 0.999 & 0.0010 \\
\hline & & & $\mathrm{HM}$ & 32.18 & 1.3047 & -0.2483 & 27.27 & 173.81 & 0.999 & 0.0041 \\
\hline \multirow{2}{*}{ (B) } & \multirow{2}{*}{$305-404$} & \multirow{2}{*}{340} & CR & 72.07 & $2.03 \times 10^{8}$ & -0.0869 & 69.24 & 98.80 & 0.978 & 0.1553 \\
\hline & & & $\mathrm{HM}$ & 77.22 & $9.76 \times 10^{9}$ & -0.0547 & 74.39 & 93.01 & 0.974 & 0.1682 \\
\hline \multirow{6}{*}{ (C) } & & & CR & 72.07 & $2.10 \times 10^{8}$ & -0.0865 & 69.29 & 98.28 & 0.978 & 0.1553 \\
\hline & $305-407$ & 335 & $\mathrm{HM}$ & 74.96 & $6.53 \times 10^{9}$ & -0.0579 & 72.18 & 91.60 & 0.974 & 0.1682 \\
\hline & & & CR & 82.88 & $1.08 \times 10^{7}$ & -0.1159 & 77.90 & 147.37 & 0.969 & 0.1984 \\
\hline & $439-604$ & 599 & $\mathrm{HM}$ & 159.41 & $1.17 \times 10^{11}$ & -0.0387 & 154.43 & 177.66 & 0.965 & 0.2023 \\
\hline & & & CR & 197.33 & $7.78 \times 10^{13}$ & 0.01433 & 191.78 & 182.22 & 0.969 & 0.1918 \\
\hline & $604-738$ & 667 & $\mathrm{HM}$ & 236.79 & $3.72 \times 10^{16}$ & 0.06563 & 231.25 & 187.47 & 0.966 & 0.2020 \\
\hline & & & CR & 72.07 & $1.95 \times 10^{8}$ & -0.0874 & 69.19 & 99.53 & 0.978 & 0.1553 \\
\hline (D) & $305-404$ & 374 & $\mathrm{HM}$ & 80.43 & $1.71 \times 10^{10}$ & -0.0525 & 77.55 & 94.99 & 0.974 & 0.1682 \\
\hline (D) & & & CR & 112.49 & $8.51 \times 10^{4}$ & -0.1578 & 106.50 & 220.32 & 0.965 & 0.2720 \\
\hline & $694-1272$ & 721 & $\mathrm{HM}$ & 98.62 & $5.29 \times 10^{4}$ & -0.16181 & 92.63 & 209.30 & 0.953 & 0.3123 \\
\hline
\end{tabular}

Where: $\left({ }^{a}\right)$ correlation coefficients of Arrhenius plots; $\left({ }^{b}\right)$ standard deviation; $\left(\right.$ Ea) the activation energy; $\left(\Delta \mathrm{S}^{*}\right)$ the entropy of activation; $\left(\Delta \mathrm{H}^{*}\right)$ the enthalpy of activation; and $\left(\Delta \mathrm{G}^{*}\right)$ Gibbs free energy.

\subsection{Antimicrobial Activity \\ 2.8.1. Antifungal Effect}

The obtained results showed that the studied GMFX-o-phelin ligand exerted promising antifungal activity against all the tested pathogenic fungi except $M$. fructicola (Table 7). Whereas the highest activity of the parent ligand was observed in the case of P. italicum at $1000 \mathrm{ppm}$ (Table 7). On the other hand, all studied metal complexes showed fungicidal effect against $A$. flavus and $B$. cinerea in a dose-dependent manner, where the highest activity was observed against A. flavus using complex (B) at $1000 \mathrm{ppm}$ and against B. cinerea using cycloximide $50 \mu \mathrm{g} / \mathrm{mL}$, complex (A) $1000 \mathrm{ppm}$ and (B) at $1000 \mathrm{ppm}$ (Table 7). The only antifungal activity against $M$. fructicola was observed in the case of (B) at the three tested concentrations. Regarding P. italicum, cycloximide $50 \mu \mathrm{g} / \mathrm{mL}$ showed the highest significant inhibition activity followed by (A) at $1000 \mathrm{ppm}$, whereas (C) at $1000 \mathrm{ppm}$ showed only moderate activity. 
Table 7. Antifungal activity assay of GMFX-o-phdn ligand and its metal complexes.

\begin{tabular}{|c|c|c|c|c|c|}
\hline \multirow{2}{*}{\multicolumn{2}{|c|}{ Treatment $(\mu \mathrm{g} / \mathrm{mL})$}} & \multicolumn{4}{|c|}{ Mycelium Growth Inhibition (\%) } \\
\hline & & \multirow{4}{*}{$\begin{array}{c}\text { M. fructicola } \\
0.0 \pm 0.0 \mathrm{c} \\
0.0 \pm 0.0 \mathrm{c} \\
0.0 \pm 0.0 \mathrm{c}\end{array}$} & \multirow{4}{*}{$\begin{array}{c}\text { A. flavus } \\
16.1 \pm 1.9 \mathrm{~b} \\
0.0 \pm 0.0 \mathrm{~d} \\
0.0 \pm 0.0 \mathrm{~d}\end{array}$} & \multirow{4}{*}{$\begin{array}{c}P . \text { italicum } \\
38.9 \pm 3.8 \mathrm{c} \\
0.0 \pm 0.0 \mathrm{~d} \\
0.0 \pm 0.0 \mathrm{~d}\end{array}$} & \multirow{4}{*}{$\begin{array}{c}\text { B. cinerea } \\
20.0 \pm 2.6 \mathrm{~b} \\
11.1 \pm 2.6 \mathrm{c} \\
0.0 \pm 0.0 \mathrm{~d}\end{array}$} \\
\hline & 1000 & & & & \\
\hline $\begin{array}{l}\text { GIVIFX-O- } \\
\text { phdn }\end{array}$ & 800 & & & & \\
\hline & 400 & & & & \\
\hline \multirow{3}{*}{ (A) } & 1000 & $0.0 \pm 0.0 c$ & $22.7 \pm 4.6 \mathrm{~b}$ & $52.9 \pm 4.1 b$ & $43.9 \pm 4.0 \mathrm{a}$ \\
\hline & 800 & $0.0 \pm 0.0 \mathrm{c}$ & $6.7 \pm 2.6 c$ & $0.0 \pm 0.0 \mathrm{~d}$ & $18.7 \pm 2.3 b$ \\
\hline & 400 & $0.0 \pm 0.0 \mathrm{c}$ & $0.0 \pm 0.0$ & $0.0 \pm 0.0 \mathrm{~d}$ & $6.7 \pm 2.3 c$ \\
\hline \multirow{3}{*}{ (B) } & 1000 & $32.6 \pm 4.5 c$ & $44.4 \pm 5.1 \mathrm{a}$ & $0.0 \pm 0.0 \mathrm{~d}$ & $38.3 \pm 5.0 \mathrm{a}$ \\
\hline & 800 & $20.6 \pm 2.2 b$ & $18.9 \pm 6.4 b$ & $0.0 \pm 0.0 \mathrm{~d}$ & $18.1 \pm 2.2 b$ \\
\hline & 400 & $5.9 \pm 1.0 \mathrm{c}$ & $4.3 \pm 1.2 \mathrm{~d}$ & $0.0 \pm 0.0 \mathrm{~d}$ & $7.9 \pm 2.2 c$ \\
\hline \multirow{3}{*}{ (C) } & 1000 & $0.0 \pm 0.0 \mathrm{c}$ & $15.8 \pm 2.3 b$ & $42.1 \pm 1.7 \mathrm{c}$ & $23.2 \pm 3.0 \mathrm{~b}$ \\
\hline & 800 & $0.0 \pm 0.0 c$ & $8.9 \pm 2.6 c$ & $0.0 \pm 0.0 \mathrm{~d}$ & $0.0 \pm 0.0 \mathrm{~d}$ \\
\hline & 400 & $0.0 \pm 0.0 \mathrm{c}$ & $0.0 \pm 0.0 \mathrm{~d}$ & $0.0 \pm 0.0 \mathrm{~d}$ & $0.0 \pm 0.0 \mathrm{~d}$ \\
\hline \multirow{3}{*}{ (D) } & 1000 & $0.0 \pm 0.0 c$ & $16.7 \pm 3.8 b$ & $0.0 \pm 0.0 \mathrm{~d}$ & $21.8 \pm 1.5 b$ \\
\hline & 800 & $0.0 \pm 0.0 c$ & $7.8 \pm 1.3 \mathrm{c}$ & $0.0 \pm 0.0 \mathrm{~d}$ & $10.4 \pm 1.5 \mathrm{c}$ \\
\hline & 400 & $0.0 \pm 0.0 \mathrm{c}$ & $2.6 \pm 0.4 \mathrm{~d}$ & $0.0 \pm 0.0 \mathrm{~d}$ & $2.4 \pm 0.3 \mathrm{~d}$ \\
\hline Cycloximide & $50 \mu \mathrm{g} / \mathrm{mL}$ & $16.1 \pm 2.8 b$ & $9.7 \pm 3.0 \mathrm{c}$ & $71.1 \pm 5.1 \mathrm{a}$ & $42.2 \pm 2.6 a$ \\
\hline
\end{tabular}

Values were recorded as the mean of growth inhibition percentage of tested pathogenic fungi (three replicates) \pm SDs. Values followed by different letters in each vertical column were significantly different according to Tukey B test at $p<0.05$. Cycloheximide: the positive control at $50 \mu \mathrm{L} / \mathrm{mL}$.

\subsubsection{Antibacterial Effect}

Regarding the antibacterial activity of the studied GMFX-o-phdn and its metal complexes, the obtained results showed that all tested treatments were able to inhibit the growth of tested pathogenic bacteria especially at the higher tested concentration $(400 \mu \mathrm{g} / \mathrm{mL})$ compared to the positive control tetracycline $(50 \mu \mathrm{g} / \mathrm{mL})$ as illustrated in Figure (2). In particular, the parent ligand showed the highest significant activity against E.coli, P. fluorescens, and P. aeruginosa where the diameters of inhibition zones were measured as 34.0,24.5, and $19.0 \mathrm{~mm}$, respectively. (C) complex showed the highest significant activity against $E$. coli $(31.0 \mathrm{~mm})$, whereas (C) and (D) complexes showed the highest significant activity against B. cereus (39.5 and $38.5 \mathrm{~mm}$, respectively) compared to all other treatments (Figure 2).

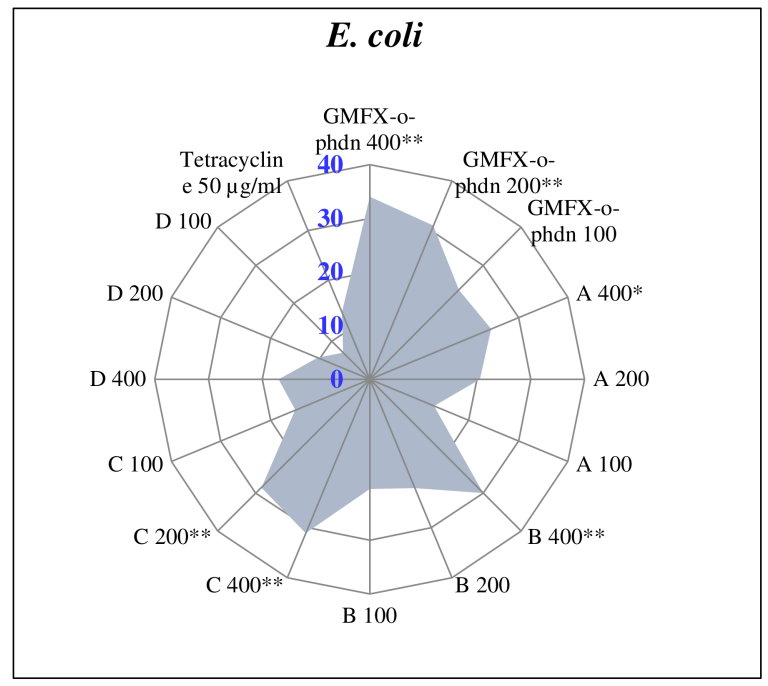

(a)

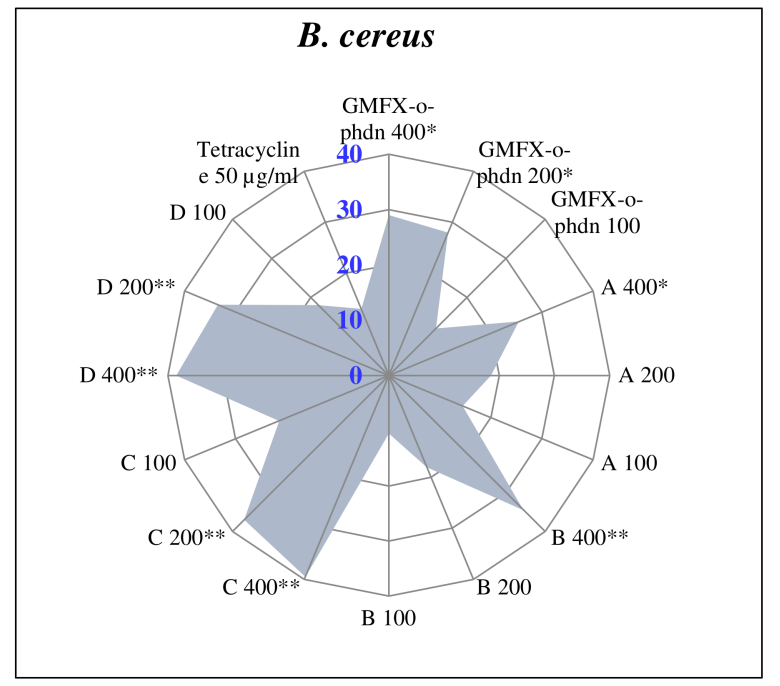

(b)

Figure 2. Cont. 


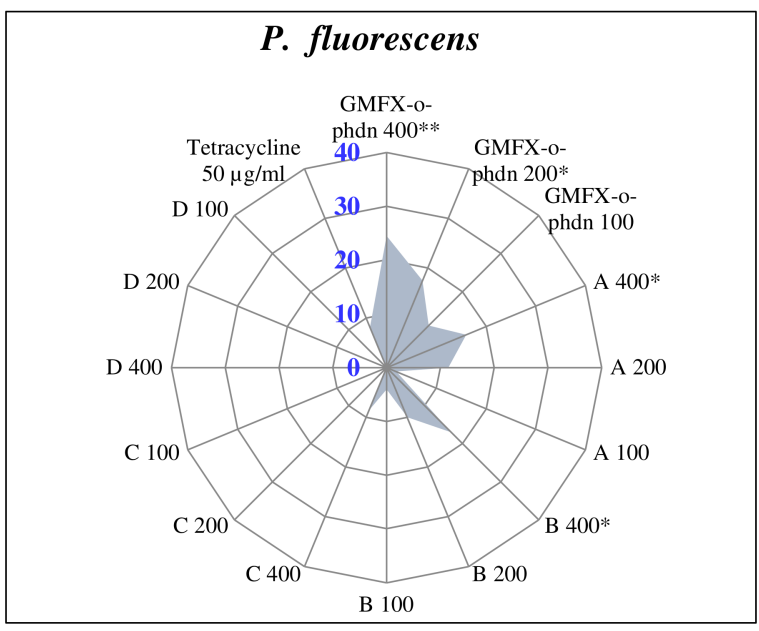

(c)

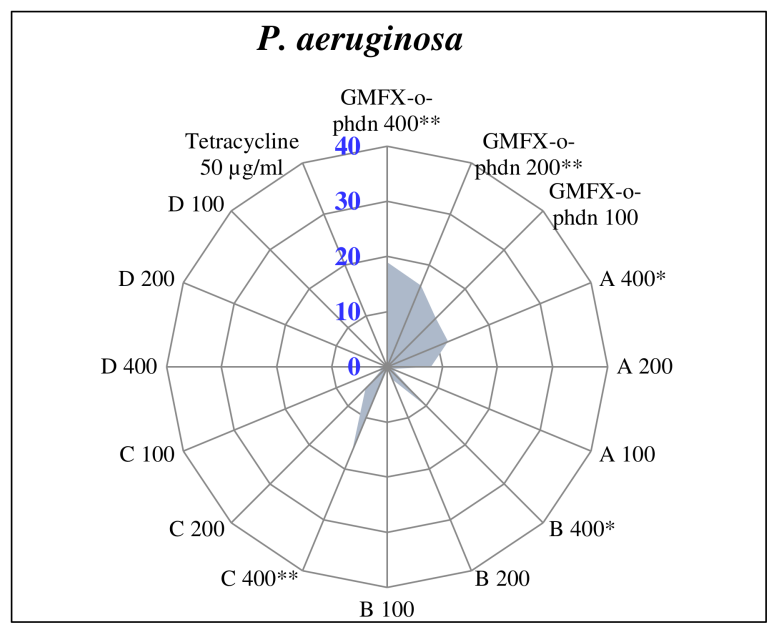

(d)

Figure 2. Antibacterial activity assay of GMFX-o-phdn and its metal complexes. Values are recorded as the mean of diameter of inhibition zones $(\mathrm{mm})$ from three replicates \pm SDs. $\left(^{*}\right)$ : statistically significant according to Tukey B test at $p<0.05$ : $\left({ }^{* *}\right)$ : statistically significant at $p<0.01$.

\subsubsection{Mechanism of Antimicrobial Action}

The obtained results of antimicrobial test showed that the tested ligands and their metal complexes were able to inhibit the growth of all studied strains in a dose-dependent manner. In particular, the fungicidal effect of the studied compounds could be due to the chemical structure of the free ligand itself as well as the toxicity of the studied metal ions [51-53]. The explanation for the promising biological activity of the studied complexes can very well be traced back to several reasons: (i) The concept of cell permeability and chelation process can reduce the polarity of a metal ion through the partial sharing of the positive charge with the donor groups of the ligand; (ii) the chelation process can also increase the delocalization of electrons on the whole chelate ring and enhance the lipophilic nature of the synthesized complex which facilitate its passage into the lipid membranes for penetrating the microbial cells [17,36]; (iii) the potential antimicrobial efficacy of the studied ligand and its metal complexes is thought to be highly related to the specific toxicity of the inorganic salts of metals ions. The obtained results gave a good insight for the possible use of these new prepared compounds for safely controlling different phytopathogens.

On the other hand, the antifungal and antibacterial activity of the studied gemifloxacin ligand and its metal complexes could be correlated also to their ability to inhibit both DNA gyrase and DNA topoisomerase IV enzymes [54]. Furthermore, various metal ions as cobalt, copper, nickel, and zinc were potentially used against several pathogens, where they form low molecular weight complexes and therefore penetrate more efficiently into microbial cells [54].

Recently, most of the antimicrobial drug resistance of some bacterial pathogens is a critical world issue especially for some important pathogens such as: E. coli, P. aeruginosa, Enterococcus spp., and Staphylococcus spp. [55,56]. Therefore, search for effective treatments and control of such serious microorganisms remains an important challenge for many researchers all over the world. Several research reported the antimicrobial activity of fluoroquinolones ligands against many pathogenic microorganisms, but they are less active against G-ve bacteria than ciprofloxacin $[57,58]$. In particular, gemifloxacin ligand demonstrated promising antimicrobial activity, compared to ciprofloxacin and levofloxacin, especially against $\mathrm{G}+$ ve bacteria such as: $S$. aureus, penicillin-susceptible and penicillin-resistant strains of Streptococcus pneumoniae [59-62]. On the other hand, some fluoroquinolones ligands such as gemifloxacin and moxifloxacin are less active against $P$. aeruginosa as is ciprofloxacin, hence the obtained results showed promising antibacterial effect against this pathogenic bacterial either in the case of GMFX-o-phdn or the complexes 
(A), (B), and (C). On the same context, the obtained results of the current research are in agreement with Morissey and Smith [63] who reported that the following three studied quinolones ligands (ofloxacin, levofloxacin, and ciprofloxacin) showed higher antibacterial activity against $P$. aeruginosa than other G-ve bacteria [64]. Meanwhile, the use of many fluoroquinolones such as gatifloxacin, moxifloxacin, and gemifloxacin in clinical field for controlling some pathogenic microorganisms resulted to be safe and had no cytotoxic effects. However, there is still concern about the possible emergence of pathogens resistance $[65,66]$.

\subsection{Antioxidant Activity}

Results of the antioxidant activity of GMFX-o-phdn and its metal complexes showed strong antioxidant effect either at 500 or $250 \mu \mathrm{g} / \mathrm{mL}$ (Figure 3). In particular, the parent ligand and G.Fe complex showed greater antioxidant capacity at low tested concentrations than that of other metal complexes where the $\mathrm{IC}_{50}$ of GMFX-o-phdn was 169.7 and $164.6 \mu \mathrm{g} / \mathrm{mL}$, respectively (Table 8). Whereas the highest significant antioxidant activity was reported for the metal complexes observed in the case of (A) complex at $500 \mu \mathrm{g} / \mathrm{mL}$ (Figure 3). On the other hand, (B) and (C) complexes showed the lowest antioxidant activity where the $\mathrm{IC}_{50}$ was 300.2 and $362.2 \mu \mathrm{g} / \mathrm{mL}$, respectively compared to other tested compounds (Table 8). The RSA \% of the GMFX-o-phdn metal complex could be due to their hydrogen donating ability $[51,67]$. In addition, the high scavenging activity of the parent ligand may explain its moderate antimicrobial effect because the reduced compounds are unable to penetrate microbial cell walls, which is characterized by its negative charge, therefore these compounds became difficult to break down and lose the microbe cytoplasm [51].

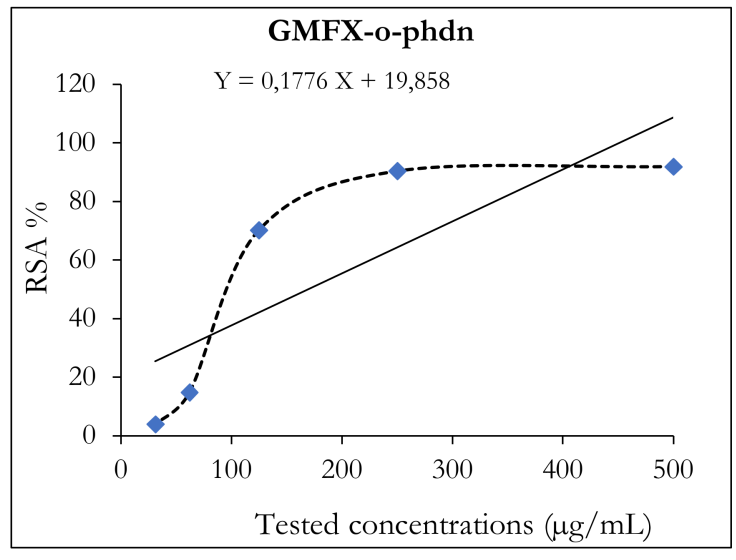

B

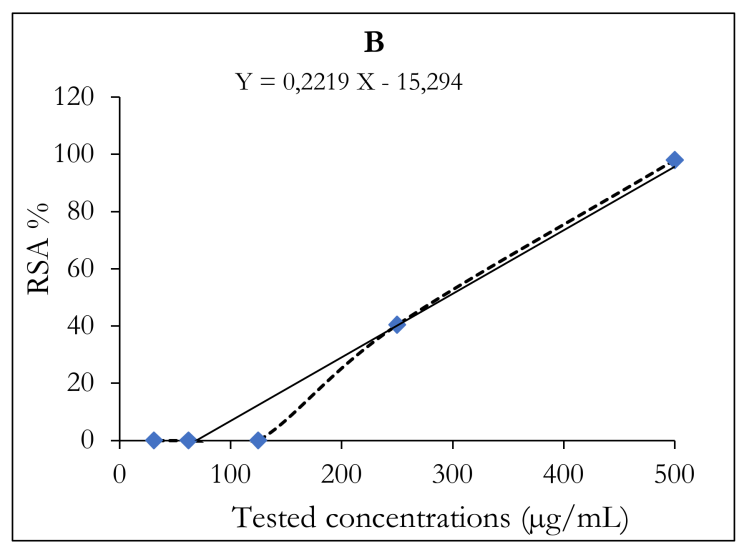

A

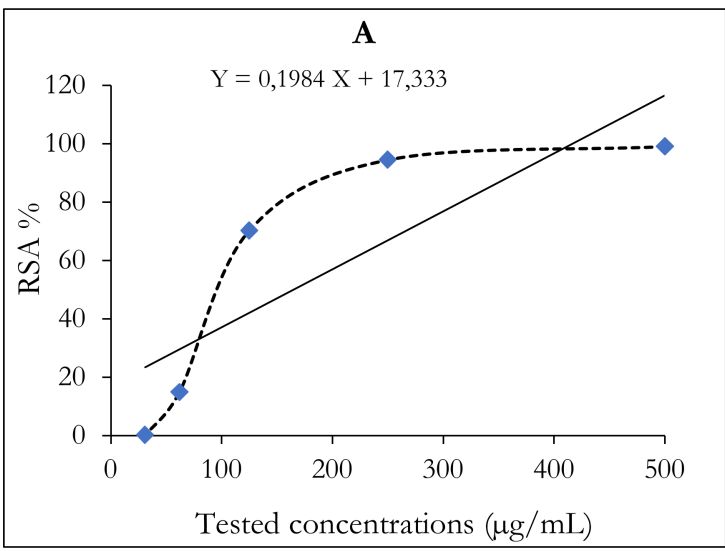

C

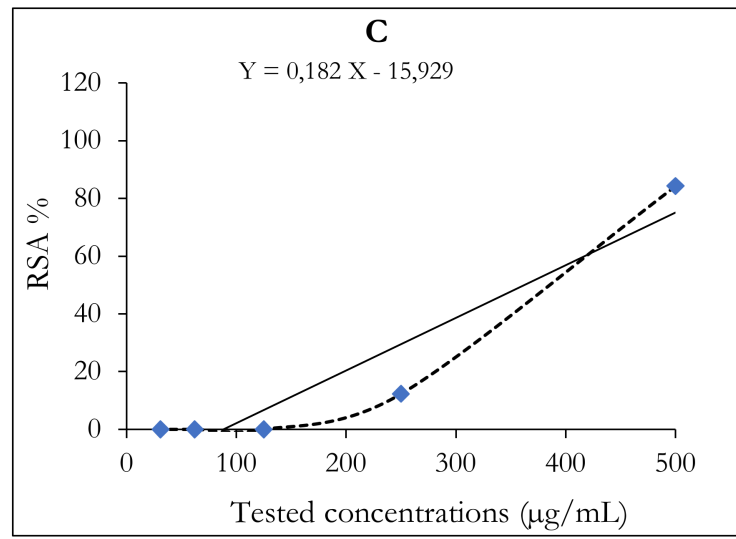

Figure 3. Cont. 


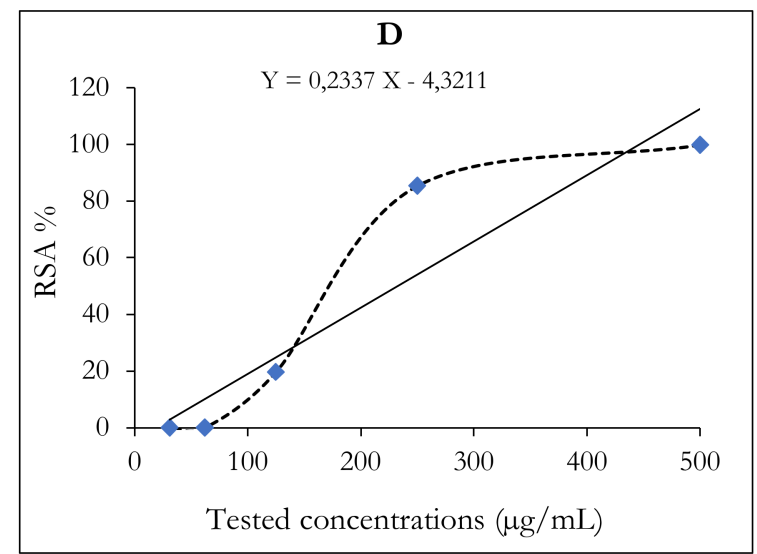

Figure 3. The radical scavenging activity (RSA\%) of the studied GMFX-o-phdn and its metal complexes using ABTS method. Where $\mathrm{IC}_{50}$ was calculated following the trend line equation equal to: $<1$, 437, 548, 472, and $673 \mu \mathrm{g} / \mathrm{mL}$ for GMFX-o-phdn, (A) Fe, (B) Zn, (C) Zr, and (D) Co, respectively.

Table 8 . The absorbance and $\mathrm{IC}_{50}$ of antioxidant activity for the studied compounds.

\begin{tabular}{|c|c|c|c|c|c|c|}
\hline \multirow{2}{*}{ Compound } & \multicolumn{5}{|c|}{ Absorbance $(734 \mathrm{~nm})$ at Different Concentrations $(\mu \mathrm{g} / \mathrm{mL})$} & \multirow{2}{*}{$\begin{array}{c}\mathrm{IC}_{50} \\
(\mu \mathrm{g} / \mathrm{mL})\end{array}$} \\
\hline & C.500 & C.250 & C.125 & C.62 & C.31 & \\
\hline $\begin{array}{l}\text { GMFX-o- } \\
\text { phdn }\end{array}$ & 0.160 & 0.191 & 0.589 & 1.685 & 1.900 & 169.7 \\
\hline A & 0.019 & 0.110 & 0.589 & 1.685 & 1.974 & 164.6 \\
\hline $\mathrm{B}$ & 0.313 & 1.733 & 2.326 & 2.377 & 2.226 & $300.2 *$ \\
\hline C & 0.006 & 0.290 & 1.590 & 2.415 & 2.196 & $362.2 *$ \\
\hline $\mathrm{D}$ & 0.040 & 1.179 & 2.191 & 2.214 & 2.158 & 232.4 \\
\hline
\end{tabular}

Where: (GMFX-o-phdn): $\mathrm{C}_{42} \mathrm{H}_{44} \mathrm{~F}_{2} \mathrm{~N}_{12} \mathrm{O}_{6} ;$ (A): $\mathrm{FeC}_{42} \mathrm{H}_{58} \mathrm{~F}_{2} \mathrm{~N}_{12} \mathrm{O}_{13} \mathrm{Cl}_{3}$; (B) $\mathrm{CoC}_{42} \mathrm{H}_{58} \mathrm{~F}_{2} \mathrm{~N}_{12} \mathrm{O}_{13} \mathrm{Cl}_{2}$; (C) $\mathrm{ZnC}_{42} \mathrm{H}_{60} \mathrm{~F}_{2} \mathrm{~N}_{12} \mathrm{O}_{14} \mathrm{Cl}_{2}$; (D) $\mathrm{ZrC}_{42} \mathrm{H}_{56} \mathrm{~F}_{2} \mathrm{~N}_{12} \mathrm{O}_{13} \mathrm{Cl}_{2}$. (*) is the highest $\mathrm{IC}_{50}$ of $\mathrm{Co}$ and $\mathrm{Zn}$ complexes indicating their lower antioxidant activity.

\section{Materials and Methods}

\subsection{Materials and Reagents}

Whole chemicals applied were of the analytical reagent grade (AR), and of highest purity available. They include gemifloxacin (GMFX), ortho-phenylenediamine (o-phdn), ferric chloride, cobalt chloride hexahydrate, zinc chloride monohydrate, zirconyl chloride heptahydrate, potassium dichromate, concentrated sulfuric acid, commercial grade concentrated nitric acid $69 \%$, hydrogen peroxide $20 \%$, disodium salt EDTA, ammonium hydroxide, ammonium chloride, Variamine Blue, Eriochrome Black T, gallein (Pyrogallolphthalein), and silver nitrate and were provided by Obour Pharmaceutical Industrial Company (Cairo, Egypt), Sigma Aldrich chemicals (Darmstadt, Germany), respectively. Organic solvents used were absolute ethyl alcohol and dimethylformamide (DMF). Distilled water was commonly applied in all preparations. All glassware were steeped overnight in chromic mixture (potassium dichromate + concentrated sulfuric acid) rinsed thoroughly with bidistiled water and dried in an oven at $100^{\circ} \mathrm{C}$.

\subsection{Preparation of GMFX-o-phdn Schiff Base}

An ethanolic solution was made by mixing GMFX ( $2 \mathrm{mmol}, 0.77 \mathrm{~g})$ with o-phenylenediamine $(1 \mathrm{mmol}, 0.108 \mathrm{~g})$ then was once refluxed in the existence of $1 \mathrm{~mL}$ of glacial acetic acid for $4 \mathrm{~h}$. The resulting combination was once settled on a water bath then cooled down to $0{ }^{\circ} \mathrm{C}$. The dark red precipitate was filtered off, washed multiple times with ethanol, and dried below vacuum over $\mathrm{CaCl}_{2}$ (Scheme 2). 

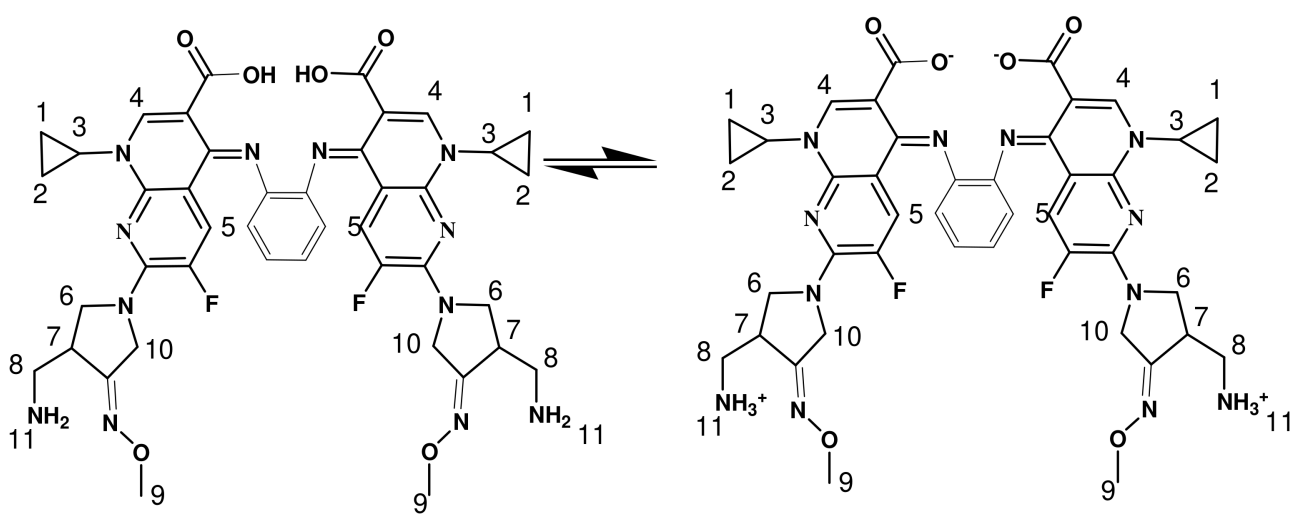

Scheme 2. Chemical structure of GMFX-o-phdn.

\subsection{Preparation of Metal Complexes}

The brown [Fe(GMFX-o-phdn) $\left.\left(\mathrm{H}_{2} \mathrm{O}\right)_{2}\right] \mathrm{Cl}_{3} .5 \mathrm{H}_{2} \mathrm{Ocomplex}$, (A) was prepared by mixing $0.5 \mathrm{mmol}(0.425 \mathrm{~g})$ of GMFX-o-phdn with $30 \mathrm{~mL}$ absolute ethanol with $0.5 \mathrm{mmol}(0.081 \mathrm{~g})$ of $\mathrm{FeCl}_{3}$ in $20 \mathrm{~mL}$ ethanol. The mixture was refluxed for $3 \mathrm{~h}$ and the precipitate was filtered off and dried under vacuum over anhydrous $\mathrm{CaCl}_{2}$. The dark green, dark brown, black solid complexes [Co(GMFX-o-phdn) $\left.\left(\mathrm{H}_{2} \mathrm{O}\right)_{2}\right] \mathrm{Cl}_{2} \cdot 5 \mathrm{H}_{2} \mathrm{O}$ (B); $\mathrm{Zn}\left(\mathrm{GMFX}\right.$-o-phdn) $\left.\left(\mathrm{H}_{2} \mathrm{O}\right)_{2}\right] \mathrm{Cl}_{2} \cdot 6 \mathrm{H}_{2} \mathrm{O}$ (C), and $\left[\mathrm{ZrO}(\mathrm{GMFX}-\mathrm{o}-\mathrm{phdn})\left(\mathrm{H}_{2} \mathrm{O}\right)\right] \mathrm{Cl}_{2} \cdot 5 \mathrm{H}_{2} \mathrm{O}(\mathrm{D})$ were prepared in a similar method described above by using $\mathrm{CoCl}_{2} \cdot 6 \mathrm{H}_{2} \mathrm{O}, \mathrm{ZnCl}_{2} \cdot \mathrm{H}_{2} \mathrm{O}$ and $\mathrm{ZrOCl}_{2} \cdot 8 \mathrm{H}_{2} \mathrm{O}$, respectively.

\subsection{Instruments}

The elemental analyses were performed using a Perkin Elmer 2400 CHN elemental analyzer. The $\mathrm{M} \%$ content was evaluated using three analytical methods like complexometric titration, thermogravimetry, and atomic absorption. For complexometric titration A digestion procedure was performed to breakdown the metal complexes. Digestion was carried out by addition of $2 \mathrm{~mL}$ nitric acid and $1 \mathrm{~mL}$ of hydrogen peroxide to the beaker containing a measured weight of metal complex. Then the beaker was placed on the hot plate temperature but not higher than $85^{\circ} \mathrm{C}$ and covered with an elevated watch glass and allowed to cool and dilute to $25 \mathrm{~mL}$ in a volumetric flask with bi-distilled water. The percentage of the metal ions were determined gravimetrically by transforming the solid products into metal oxide, and also by using atomic absorption method [25]. Atomic absorption analysis was carried out by direct method to estimate the total metal content at the corresponding wavelength. Several reference standard solutions of each metal were prepared with a specific concentration. Spectrometer model PYE-UNICAM SP 1900 fitted with the corresponding lamp was used for this purpose. FT-IR spectra in $\mathrm{KBr}$ discs were recorded in the range from $4000-400 \mathrm{~cm}^{-1}$ with FT-IR 460 PLUS Spectrophotometer. ${ }^{1} \mathrm{H}$ NMR spectra were recorded on Varian Mercury VX-300 NMR Spectrometer using DMSO- $\mathrm{d}_{6}$ as the solvent. TG-DTG measurements were done under $\mathrm{N}_{2}$ atmosphere within the temperature range from room temperature to $1000{ }^{\circ} \mathrm{C}$ using TGA-50H Shimadzu, the mass of sample was accurately weighted out in an aluminum crucible. Electronic spectra were analyzed using UV-3101PC Shimadzu. The absorption spectra were recorded as solutions in DMSO- $\mathrm{d}_{6}$. Room temperature magnetic susceptibilities of the powdered samples were analyzed on a Sherwood scientific magnetic balance using Gouy balance at room temperature using $\mathrm{Hg}\left[\mathrm{Co}(\mathrm{CSN})_{4}\right]$ as the calibrant. Melting points were recorded on a Buchi apparatus. All measurements were carried out at ambient temperature with freshly prepared solutions. The molar conductance of $1 \times 10^{-3} \mathrm{M}$ solutions of the ligands and their complexes in DMF was measured at room temperature using CONSORT K410.

\subsection{Antifungal Activity Assay}

Tested fungi. The following tested phytopathogenic fungi, Monilinia fructicola, Aspergillus flavus, Penicillium italicum, and Botrytis cinerea, were cultured on potato dextrose 
agar (PDA) and stored at $4{ }^{\circ} \mathrm{C}$ as pure cultures in the mycotheca of School of Agricultural, Forestry, Food and Environmental Sciences (SAFE), University of Basilicata, Potenza, Italy. All tested fungi were previously identified by morphological and molecular methods. Fungicidal assay. The fungicidal activity of the tested compounds was determined by incorporation assay in PDA medium [65] at concentrations 1000, 800, and $400 \mu \mathrm{g} / \mathrm{mL}$. PDA Petri dishes $(\varnothing 90 \mathrm{~mm})$ were inoculated with each single fungal disks $(\varnothing 5 \mathrm{~mm})$. All plates were incubated at $22 \pm 2{ }^{\circ} \mathrm{C}$ for $96 \mathrm{~h}$ and the antifungal effect was evaluated by measuring the diameter of the mycelium growth $(\mathrm{mm})$. The growth inhibition percentage $(\mathrm{GI} \%)$ was calculated according to Zygadlo et al. [66] (Formula 1) compared to cycloheximide $50 \mu \mathrm{L} / \mathrm{mL}$.

$$
\mathrm{GI}(\%)=\frac{(\mathrm{Gc}-\mathrm{Gt})}{\mathrm{Gc}} \times 100
$$

where GI (\%) is the percentage of mycelium growth inhibition, Gc is the average diameter of fungal mycelium in PDA (control), and Gt is the average diameter of fungal mycelium on the treated PDA dish.

\subsection{Antibacterial Activity Assay}

Tested bacteria. The tested pathogenic bacterial strains Escherichia coli, Bacillus cereus, Pseudomonas fluorescens, and P. aeruginosa were conserved as pure cultures in the collection of SAFE.

Bactericidal assay. The antibacterial activity of the tested compounds were evaluated following the disc diffusion method $[65,66]$. For this trial, the bacterial suspension of each tested strain was prepared in sterile Millipore $\mathrm{H}_{2} \mathrm{O}$ and incorporated with soft agar $(0.7 \%)$ at ratio $1: 9(v / v)$ to reach $10^{8}$ colony forming units $(\mathrm{CFU} / \mathrm{mL})$. Four milliliter of each suspension was poured in Petri dishes (Ø $90 \mathrm{~mm}$ ) filled with king B nutrient media (KB). Blank discs $(6 \mathrm{~mm})$ (OXOID, Milan, Italy) were placed on each Petri dish and $15 \mu \mathrm{L}$ of each tested compound was added at 400, 200, and $100 \mu \mathrm{g} / \mathrm{mL}$ concentrations. Tetracycline $(50 \mu \mathrm{g} / \mathrm{mL})$ was used as positive control. The antimicrobial effect was determined after $24 \mathrm{~h}$ at $37^{\circ} \mathrm{C}$ by measuring the average diameter of inhibition zones $(\mathrm{mm}) \pm$ SDs of three replicates.

\subsection{Antioxidant Activity}

Antiradical activity of the studied compounds was evaluated using 2,2'-azinobis (3ethylbenzthiazoline-6-acid) $\left(\mathrm{ABTS}^{\bullet+}\right)$ assay following the methodological procedures of the basic principles of Martysiak-Żurowska and Wenta [68]. The ABTS method is considered the most sensitive method and is characterized by higher repeatability for observing the kinetics of specific enzymes. The detectability and sensitivity of ABTS ${ }^{\bullet+}$ are higher than the DPPH (2,2-diphenyl-1-picrylhydrazyl) assay [51,69]. The stock solution of the ABTS radical was prepared by dissolving $38 \mathrm{mg}$ of ABTS in $10 \mathrm{~mL}$ of an aqueous sodium persulphate solution $(2.45 \mathrm{mM})$. The mixture was dark stored for $16 \mathrm{~h}$. For the analysis, $1 \mathrm{~mL}$ of stock ABTS $^{\bullet+}$ solution was diluted in ethanol (1:30). Twenty microliter of sample was added to $980 \mu \mathrm{L}$ of $\mathrm{ABTS}^{\bullet+}$ solution for $2 \mathrm{~h}$ in dark at room temperature. After centrifuging ( $5 \mathrm{~min}$, $8000 \mathrm{rpm}$ ), absorbance was measured at $734 \mathrm{~nm}$ against the reference solvent (ethanol). The solutions were prepared fresh for the analysis and all determinations were carried out in triplicate. Evaluation of the radical scavenging activity (RSA\%) of the studied ligand and its metal complexes was carried out at 250,500,1000, and $2000 \mu \mathrm{g} / \mathrm{mL}$ concentrations (Formula (2)):

$$
\text { RSA \% }=\left(1-A_{t} / A_{c}\right) \times 100 \% ;
$$

where $A_{t}$ is the absorbance of sample and $A_{c}$ is the absorbance of colorimetric radical substance without sample.

\subsection{Statistical Analysis}

The obtained results of the antimicrobial assays were subjected to one-way ANOVA for the statistical analysis. The significance level of the outfindings was checked by applying 
Tukey B Post Hoc multiple comparison test with a probability of $p<0.05$ using statistical Package for the Social Sciences (SPSS) version 13.0 (Prentice Hall: Chicago, IL, USA, 2004).

\section{Conclusions}

Chemical structures of a novel GMFX-o-phdn Schiff base ligand and its mononuclear metal complexes were portrayed employing diverse physicochemical techniques. The current research disclosed an octahedral geometry around the metal complexes as specified from UV-Visible spectra and magnetic moment measurements. IR spectra disclosed that the bis-Schiff base ligand acts as a tetra dentate ligand and its pattern of coordination is through the nitrogen atoms of the azomethine and oxygen of the carboxylate group. The thermal behavior was studied in order to give an idea about thermal decomposition of the complexes. Moreover, ${ }^{1} \mathrm{H}$ NMR spectra for complexes demonstrate a new peak at 3.45 and $3.50 \mathrm{ppm}$, due to the existence of water molecules in the complexes. On the other hand, the studied complexes exhibited promising antimicrobial activity against most of the tested phytopathogens and strong antioxidant effect.

Supplementary Materials: The following are available online at https:/ /www.mdpi.com/article/10 $.3390 / \mathrm{ijms} 23042110 / \mathrm{s} 1$.

Author Contributions: Conceptualization, S.A.S. and A.A.M.; data curation, H.S.E. and I.C.; formal analysis, H.S.E.; investigation, S.A.S.; methodology, H.S.E., I.C. and A.A.M.; supervision, S.A.S. and I.C.; visualization, A.A.M.; writing-original draft, H.S.E. and A.A.M.; writing-review and editing, S.A.S. and I.C. All authors have read and agreed to the published version of the manuscript.

Funding: This research received no external funding.

Institutional Review Board Statement: Not applicable.

Informed Consent Statement: Not applicable.

Data Availability Statement: Not applicable.

Conflicts of Interest: The authors declare no conflict of interest.

\section{References}

1. Wallis, S.; Gahan, L.; Charles, B.; Hambley, T. 13C N.M.R. and Single-Crystal X-ray Structural Investigation of the Fluoroquinolone Antimicrobial Drug Norfloxacin 2DCl.D2O. Aust. J. Chem. 1994, 47, 799-806. [CrossRef]

2. Turel, I.; Bukovec, P. Comparison of the thermal stability of ciprofloxacin and its compounds. Thermochim. Acta 1996, 287, 311-318. [CrossRef]

3. Cygler, M.; Huber, C.P. Structure of oxolinic acid, a potent antibacterial agent.1-Ethyl-1,4-di-hydro-6,7-methylene-dioxy-4-oxo-3quinoline-carboxylic acid, $\mathrm{C}_{13} \mathrm{H}_{11} \mathrm{NO}_{5}$. Acta Crystallogr. 1985, 41, 1052-1055.

4. Zordok, W.A. Interaction of vanadium (IV) solvates (L) with second-generation fluoroquinolone antibacterial drug ciprofloxacin: Spectroscopic, structure, thermal analyses, kinetics and biological evaluation (L=An, DMF, Py and Et3N). Spectrochim. Acta Part A Mol. Biomol. Spectrosc. 2014, 129, 519-536. [CrossRef] [PubMed]

5. Florence, A.J.; Kennedy, A.R.; Shankland, N.; Wright, E.; Al Rubayi, A. Norfloxacin dehydrate. Acta Crystallogr. 2000, 56, $1372-1373$.

6. Turel, I.; Bukovec, P.; Quiros, M. Gel Growth, XRD, SEM and Spectral Studies of Ciprofloxacin Hexa-hydrate. Int. J. Pharm. 1997, 152, 59. [CrossRef]

7. Sivalakshmidevi, A.; Vyas, K.; Om Reddy, G. Sparfloxacin, an antibacterial drug. Acta Crystallogr. 2000, 56, 115-116. [CrossRef] [PubMed]

8. Ruiz, M.; Perellò, L.; Ortiz, R.; Castiñeiras, A.; Maichle-Mösser, C.; Cantòn, E. Synthesis, characterization, and crystal structure of [Cu(cinoxacinate)2]. 2H2O complex: A squareplanar $\mathrm{CuO} 4$ chromophore. Antibacterial studies. J. Inorg. Biochem. 1995, 59, 801-810. [CrossRef]

9. Ruiz, M.; Ortiz, R.; Perelló, L.; Latorre, J.; Server-Carrió, J. Potentiometric and spectroscopic studies of transition-metal ions complexes with a quinolone derivative (cinoxacin). Crystal structures of new $\mathrm{Cu}(\mathrm{II})$ and $\mathrm{Ni}$ (II) cinoxacin complexes. J. Inorg. Biochem. 1997, 65, 87-96. [CrossRef]

10. Turel, I.; Leban, I.; Bukovec, N. Crystal structure and characterization of the bismuth(III) compound with quinolone family member (ciprofloxacin). Antibacterial study. J. Inorg. Biochem. 1997, 66, 241-245. [CrossRef]

11. Firuzabadi, F.D.; Asadi, Z. Experimental and computational studies of the interaction of gemifloxacin and manganese (II) gemifloxacin complex with DNA. J. Mol. Struct. 2020, 1224, 129248. [CrossRef] 
12. Grossman, R.F.; Rotschafer, J.C.; Tan, J.S. Antimicrobial treatment of lower respiratory tract infections in the hospital setting. Am. J. Med. 2005, 118, 29-38. [CrossRef] [PubMed]

13. Kan, J.-Y.; Hsu, Y.-L.; Chen, Y.-H.; Chen, T.-C.; Wang, J.-Y.; Kuo, P.-L. Gemifloxacin, a Fluoroquinolone Antimicrobial Drug, Inhibits Migration and Invasion of Human Colon Cancer Cells. BioMed Res. Int. 2013, 2013, 1-11. [CrossRef] [PubMed]

14. Tuma, J.; Connors, W.H.; Stitelman, D.H.; Richert, C. On the Effect of Covalently Appended Quinolones on Termini of DNA Duplexes. J. Am. Chem. Soc. 2002, 124, 4236-4246. [CrossRef] [PubMed]

15. Aslan, N.; Büyükgüzel, E.; Büyükgüzel, K. Oxidative effects of gemifloxacin on some biological traits of Drosophila Melanogaster (Diptera: Drosophilidae). Environ. Entomol. 2019, 48, 667-673. [CrossRef] [PubMed]

16. Mishra, D.K.; Mishra, A.P. Synthesis structural characterization and biological significance of some novel Schiff base complexes with Co (II), Ni (II) and Cu (II). Int. J. Pharm. Res. Dev. 2011, 3, 24-31.

17. Mohamed, A.A.; Elshafie, H.S.; Sadeek, S.A.; Camele, I. Biochemical Characterization, Phytotoxic Effect and Antimicrobial Activity against Some Phytopathogens of New Gemifloxacin Schiff Base Metal Complexes. Chem. Biodivers. 2021. [CrossRef] [PubMed]

18. Mohamed, G.G. Synthesis, characterization and biological activity of bis(phenylimine) Schiff base ligands and their metal complexes. Spectrochim. Acta Part A Mol. Biomol. Spectrosc. 2006, 64, 188-195. [CrossRef] [PubMed]

19. Zhao, Y. Liquid chromatographic determination of chelates of cobalt (II), copper (II) and iron (II) with 2-thiophonaldehyde-4phenyl-3-thiosemicarbazone. Chromatographia 2000, 51, 231-234. [CrossRef]

20. Tsukube, H.; Shinoda, S. Lanthanide Complexes in Molecular Recognition and Chirality Sensing of Biological Substrates. Chem. Rev. 2002, 102, 2389-2404. [CrossRef]

21. Chohana, Z.H.; Perveza, H.; Raufb, A.; Khanc, K.M.; Supurand, C.T. Isatin-derived Antibacterial and Antifungal Com-pounds and their Transition Metal Complexes. J. Enzym. Inhib. Med. Chem. 2004, 19, 417-423. [CrossRef] [PubMed]

22. Premkumar, T.; Govindarajan, S. Antimicrobial study on trivalent lighter rare-earth complexes of 2-pyrazinecarboxylate with hydrazinium cation. World J. Microbiol. Biotechnol. 2006, 22, 1105-1108. [CrossRef]

23. Dhar, D.N.; Saxena, P.N.; Kumar, S. Applications of metal complexes of Schiff bases-A review. J. Sci. Ind. Res. 2009, 68, 181-187.

24. Rajesh, P.; Gunasekaran, S.; Manikandan, A. Structural, spectral analysis of ambroxol using DFT methods. J. Mol. Struct. 2017, 1144, 379-388. [CrossRef]

25. Abd El-Hamid, S.M.; Sadeek, S.A.; El-Farargy, A.F.; Abd El-Lattif, N.S. Synthesis, structural characterization and ne-maticidal studies of some new N2O2 Schiff base metal complexes. Bull. Chem. Soc. Ethiop. 2021, 35, 315-335. [CrossRef]

26. Mahmoud, W.H.; Mohamed, G.G.; Elsawy, H.A.; Radwan, M.A. Metal complexes of novel Schiff base derived from the condensation of 2-quinoline carboxaldehyde and ambroxol drug with some transition metal ions. Appl. Organomet. Chem. 2018, 32, e4392. [CrossRef]

27. Tarushi, A.; Psomas, G.; Raptopoulou, C.P.; Psycharis, V.; Kessissoglou, D.P. Structure and DNA-binding properties of bis(quinolonato)bis(pyridine)zinc(II) complexes. Polyhedron 2009, 28, 3272-3278. [CrossRef]

28. Norouzian, H.; Shahrokhi, N.; Sabeti, S.; Bouzari, S.; Pooya, M. Evaluation of Quinolone Resistance in Escherichia coli Isolates Recovered from Urine and Feces of Patients with Acute or Recurrent Urinary Tract Infection. J. Med. Microbiol. Infect. Dis. 2019, 7 , 120-126. [CrossRef]

29. El-Attar, M.S.; Sadeek, S.A.; El-Farargy, A.F.; El-Lattif, N.S.A.; El-Hamid, S.M.A. Spectroscopic, thermal analyses, XRD spectra and nematicidal activity study of some new N2O2 tetradentate Schiff base metal ions complexes. Bull. Chem. Soc. Ethiop. 2021, 35 , 381-397. [CrossRef]

30. Geary, W.J. The use of conductivity measurements in organic solvents for the characterization of coordination compounds. Coord. Chem. Rev. 1971, 7, 81-122. [CrossRef]

31. Ahmed, F.M.; Sadeek, S.A.; El-Shwiniy, W. Synthesis, Spectroscopic Studies, and Biological Activity of Some New $\mathrm{N}_{2} \mathrm{O}_{2}$ Tetradentate Schiff Base Metal Complexes. Russ. J. Gen. Chem. 2019, 89, 1874-1883. [CrossRef]

32. Elshafie, H.; Sadeek, S.; Zordok, W.; Mohamed, A. Meloxicam and Study of Their Antimicrobial Effects against Phyto- and Human Pathogens. Molecules 2021, 26, 1480. [CrossRef] [PubMed]

33. Chandra, S.; Kumar, U. Studies on the synthesis, stereochemistry and antifungal properties of coumarin thiosemicarbazone and its $\mathrm{Ni}$ (II) and Cu (II) complexes. J. Saudi. Chem. Soc. 2004, 8, 77-84.

34. Sadeek, S.A.; El-Attar, M.S.; El-Hamid, S.M.A. Synthesis and characterization and antibacterial activity of some new transition metal complexes with ciprofloxacin-imine. Bull. Chem. Soc. Ethiop. 2015, 29, 259-274. [CrossRef]

35. Gaber, M.; El-Sayed, Y.S.; El-Baradie, K.; Fahmy, R.M. Cu(II) complexes of monobasic bi- or tridentate (NO, NNO) azo dye ligands: Synthesis, characterization, and interaction with Cu-nanoparticles. J. Mol. Struct. 2013, 1032, 185-194. [CrossRef]

36. El-Shwiniy, W.H.; Gamil, M.A.; Sadeek, S.A.; Zordok, W.A. Study molecular modeling and the effect of some biological metals on the efficiency of norfloxacin in presence of 3-(bromoacetyl)coumarin. Appl. Organomet. Chem. 2021, 35, e6178. [CrossRef]

37. Sadeek, S.A.; EL-Shwiniy, W.H.; Zordok, W.A.; EL-Didamony, A.M. Spectroscopic, structure and antimicrobial activity of new Y (III) and Zr (IV) ciprofloxacin. Spectrochim. Acta Part A 2011, 78, 854-867. [CrossRef]

38. Sadeek, S.; El-Attar, M.; El-Hamid, S.A. Preparation and characterization of new tetradentate Schiff base metal complexes and biological activity evaluation. J. Mol. Struct. 2013, 1051, 30-40. [CrossRef]

39. Elshwiniy, W.H.; Ibrahim, A.G.; Sadeek, S.A.; Zordok, W.A. Ligational, density functional theory, and biological studies on some new Schiff base 2-(2-hydroxyphenylimine) benzoic acid (L) metal complexes. Appl. Organomet. Chem. 2020, 34, e5819. [CrossRef] 
40. Psomas, G.; Tarushi, A.; Efthimiadou, E.K. Synthesis, characterization and DNA-binding of the mononuclear dioxoura-nium(VI) complex with ciprofloxacin. Polyhedron 2008, 27, 133-138. [CrossRef]

41. Saif, M.; Mashaly, M.M.; Eid, M.F.; Fouad, R. Synthesis, characterization and thermal studies of binary and/or mixed ligand complexes of $\mathrm{Cd}(\mathrm{II}), \mathrm{Cu}(\mathrm{II}), \mathrm{Ni}$ (II) and $\mathrm{Co}(\mathrm{III})$ based on 2-(Hydroxybenzylidene) thiosemicarbazone: DNA binding affinity of binary Cu(II) complex. Spectrochim. Acta Part A Mol. Biomol. Spectrosc. 2012, 92, 347-356. [CrossRef]

42. Mondal, N.; Dey, D.K.; Mitra, S.; Malik, K. Synthesis and structural characterization of mixed ligand $\eta 1$-2-hydroxyacetophenone complexes of cobalt(III). Polyhedron 2000, 19, 2707-2711. [CrossRef]

43. Sadeek, S.A.; Abd El-Hamid, S.M.; Zordok, W.A. Spectroscopic, DFT and antimicrobial activity of Zn (II), Zr (IV), Ce (IV) and $\mathrm{U}$ (VI) complexes of N, N-chelated 4, 6-bis (4-chlorophenyl)-2-amino-1, 2-dihydropyridine-3. Appl. Organomet. Chem. 2018, 32, e4457. [CrossRef]

44. Abd El-Hamid, S.M.; Sadeek, S.A.; Zordok, W.A.; Rashid, N.G. Spectroscopic properties, molecular structure, anticancer and antimicrobial evaluation of some new moxifloxacin metal complexes in the presence of 1,10-phenanthroline. Bull. Chem. Soc. Ethiop. 2020, 34, 295-312. [CrossRef]

45. Mohamed, G.G.; Zayed, E.M.; Hindy, A.M. Coordination behavior of new bis Schiff base ligand derived from 2-furan carboxaldehyde and propane-1,3-diamine. Spectroscopic, thermal, anticancer and antibacterial activity studies. Spectrochim. Acta Part A Mol. Biomol. Spectrosc. 2015, 145, 76-84. [CrossRef] [PubMed]

46. Sadeek, S.; El-Hamid, S.A. Preparation, characterization and cytotoxicity studies of some transition metal complexes with ofloxacin and 1,10-phenanthroline mixed ligand. J. Mol. Struct. 2016, 1122, 175-185. [CrossRef]

47. Skauge, T.; Turel, I.; Sletten, E. Interaction between ciprofloxacin and DNA mediated by $\mathrm{Mg}^{2+}$-ions. Inorganica Chim. Acta 2002, 339, 239-247. [CrossRef]

48. Coats, A.W.; Redfern, J.P. Kinetic parameters from thermogravimetric data. Nature 1964, 20, 68-69. [CrossRef]

49. Horowitz, H.H.; Metzger, G. A New Analysis of Thermogravimetric Traces. Anal. Chem. 1963, 35, 1464-1468. [CrossRef]

50. El-Gammal, O. Mononuclear and binuclear complexes derived from hydrazone Schiff base NON donor ligand: Synthesis, structure, theoretical and biological studies. Inorganica Chim. Acta 2015, 435, 73-81. [CrossRef]

51. Sakr, S.H.; Elshafie, H.S.; Camele, I.; Sadeek, S.A. Synthesis, Spectroscopic, and Biological Studies of Mixed Ligand Com-plexes of Gemifloxacin and Glycine with Zn(II), Sn(II), and Ce(III). Molecules 2018, 23, 1182. [CrossRef] [PubMed]

52. Elshafie, H.S.; Sakr, S.H.; Sadeek, S.A.; Camele, I. Biological investigations and spectroscopic studies of new Moxifloxacin/Glycine-Metal complexes. Chem. Biodivers. 2018, 16, e1800633. [CrossRef] [PubMed]

53. Elshafie, H.; Sadeek, S.; Camele, I.; Awad, H.; Mohamed, A. Biological and Spectroscopic Investigations of New Tenoxicam and 1.10-Phenthroline Metal Complexes. Molecules 2020, 25, 1027. [CrossRef] [PubMed]

54. Heaton, V.J.; Ambler, J.E.; Fisher, L.M. Potent Antipneumococcal Activity of Gemifloxacin Is Associated with Dual Targeting of Gyrase and Topoisomerase IV, an In Vivo Target Preference for Gyrase, and Enhanced Stabilization of Cleavable Complexes In Vitro. Antimicrob. Agents Chemother. 2000, 44, 3112-3117. [CrossRef] [PubMed]

55. Adesiyun, A.; Offiah, N.; Seepersadsingh, N.; Rodrigo, S.; Lashley, V.; Musai, L. Antimicrobial resistance of Salmonella spp. and Escherichia coli isolated from table eggs. Food Control 2007, 18, 306-311. [CrossRef]

56. Rodrigo, S.; Adesiyun, A.; Asgarali, Z.; Swanston, W. Antimicrobial resistance of Campylobacter spp. isolated from broilers in small poultry processing operations in Trinidad. Food Control 2007, 18, 321-325. [CrossRef]

57. Tanaka, M.; Tunoe, H.; Mochida, O.; Kanayama, A.; Saika, T.; Kobayashi, I.; Naito, S. Antimicrobial activity of gemifloxacin (SB-265805), a newer fluoroquinolone, against clinical isolates of Neisseria gonorrhoeae, including fluoroquinolone-resistant isolates. Diagn. Microbiol. Infect. Dis. 2000, 38, 109-113. [CrossRef]

58. Grasela, D.M. Clinical Pharmacology of Gatifloxacin, a New Fluoroquinolone. Clin. Infect. Dis. 2000, 31, S51-S58. [CrossRef]

59. Hoban, D.; Bouchillon, S.; Johnson, J.; Zhanel, G.; Butler, D.; Miller, L.; Poupard, J. Comparative in vitro activity of gemifloxacin, ciprofloxacin, levofloxacin and ofloxacin in a North American surveillance study. Diagn. Microbiol. Infect. Dis. 2001, 40, 51-57. [CrossRef]

60. Fernandez-Roblas, R.; Cabria, F.; Esteban, J.; López, J.C.; Gadea, I.; Soriano, F. In vitro activity of gemifloxacin (SB-265805) compared with 14 other antimicrobials against intestinal pathogens. J. Antimicrob. Chemother. 2000, 46, 1023-1027. [CrossRef]

61. Saravolatz, L.; Manzor, O.; Check, C.; Pawlak, J.; Belian, B. Antimicrobial activity of moxifloxacin, gatifloxacin and six fluoroquinolones against Streptococcus pneumoniae. J. Antimicrob. Chemother. 2001, 47, 875-877. [CrossRef] [PubMed]

62. Cottagnoud, P.; Acosta, F.; Cottagnoud, M.; Taäuber, M.G. Gemifloxacin Is Efficacious against Penicillin-Resistant and QuinoloneResistant Pneumococci in Experimental Meningitis. Antimicrob. Agents Chemother. 2002, 46, 1607-1609. [CrossRef]

63. Morissey, I.; Smith, J.T. Activity of 4-quinolones against Pseudomonas aeruginosa. Arzneimittel-Forschung 1994, 44, 1157-1161. [PubMed]

64. Scheld, W.M. Maintaining Fluoroquinolone Class Efficacy: Review of Influencing Factors. Emerg. Infect. Dis. 2003, 9, 1-9. [CrossRef] [PubMed]

65. Elshafie, H.; Mancini, E.; Camele, I.; De Martino, L.; De Feo, V. In vivo antifungal activity of two essential oils from Mediterranean plants against postharvest brown rot disease of peach fruit. Ind. Crop. Prod. 2015, 66, 11-15. [CrossRef]

66. Zygadlo, J.A.; Guzman, C.A.; Grosso, N.R. Antifungal properties of the leaf oils of Tagetes minuta L. and Tagetes filifolia Lag. J. Essent. Oil Res. 1994, 6, 617-621. [CrossRef] 
67. Corona-Bustamante, A.; Viveros-Paredes, J.M.; Flores-Parra, A.; Peraza-Campos, A.L.; Martínez-Martínez, F.J.; Suma-ya-Martínez, M.T.; Ramos-Organillo, Á. Antioxidant Activity of Butyl- and Phenylstannoxanes Derived from 2-, 3- and 4-Pyridinecarboxylic Acids. Molecules 2010, 15, 5445-5459. [CrossRef]

68. Martysiak-Żurowska, D.; Wenta, W. A comparison of ABTS and DPPH methods for assessing the total antioxidant capacity of human milk. Acta Sci. Pol. Technol. Aliment. 2012, 11.

69. Cosentino, C.; Labella, C.; Elshafie, H.; Camele, I.; Musto, M.; Paolino, R.; D'Adamo, C.; Freschi, P. Effects of different heat treatments on lysozyme quantity and antimicrobial activity of jenny milk. J. Dairy Sci. 2016, 99, 5173-5179. [CrossRef] 